Tér és Társadalom 18. évf. 2004/1. 1-41. p.

Tér és Társadalom

XVIII. évf. 2004 - 1: 1-41

\title{
FEL IS ÚT, LE IS ÚT... (VÁROSAINK TELEPÜLÉSHIERARCHIÁBAN ELFOGLALT POZÍCIÓINAK VÁLTOZÁSAI A 20. SZÁZADBAN)
}

\author{
(Rise and fall... \\ Changes in Hierarchical Position of the Hungarian Cities \\ in the XX. Century)
}

BELUSZKY PÁL - GYÖRI RÓBERT

Kulcsszavak:

történetiföldrajz városfogalon településhierarchia városhálózat

A tanulmány több idökeresztmetszetre - 1910, 1965, 1995, 2000 - készített empirikus hierarchiavizsgálat, illetve a városi funkciók mennyiségi oldalának meghatározâsára végzett számítisok eredményeit veti össze a városhálózatban bekövetkezett változások felmérése céljából. A szerzôk megállapítása. hogy a 20. szízad urbanizaciója nem járt a városi funkciójú telepuilések számának látványos emelkedésével; hogy a városhierarchia struktúrája szilârdnak bizonyult a magunk mögött hagyott évszázadban, niközben az egyes hierarchia-szintek állománya természetesen cserélödött. A szerzök a telepulilésfejlesztés figyelmébe ajánlják a hierarchikus poziciójukban erösen visszaesö városokat (Sátoraljaújhely, Balassagyarmat, Jászberény, Makó, Mohács stb.). A városhierarchiában való emelkedésnek három mozgatórugója volt a 20. században: az iparositás, az agglomerálódás és az idegenforgalom.

\section{Városfogalom, városkutatás}

A napjainkban leginkább elfogadott - földrajzi, településtudományi - álláspont szerint a város a településállományon belül kialakult földrajzi munkamegosztás terméke; e munkamegosztásban a központi szerepkört betöltö település, amelyben a városi alapfunkciók megfelelö mennyisége és sokfélesége tömörült; olyan település tehát, ahol a lakosság nem mindennapi igényeit kjelégítỏ tevékenységek, intézmények koncentrálódnak. Településhálózati szerepénél, „hivatásánál” fogva tehát a város a csere, az érintkezés, a ,találkozás” kitüntetett szintere a területi munkamegosztás által strukturált világban; természetesen nemcsak az áruk cseréjének, hanem a tudás, az információ, a „kultúrák”, az eszmék cseréjének is. A központi szerepkörre támaszkodva a város jelentős térszervezỏ erővel rendelkezik, s gyakorta döntési, hatalmi központ. ${ }^{1}$

A fentiekből következik, hogy nem minden, a környező „,vidékhez” füződő településközi kapcsolatokkal rendelkezó település számít városnak: elaprózott településszerkezetü, aprófalvas területeken az alapfokú intézmények több környezó települést láthatnak el szolgáltatásaikkal (körjegyző, „körzeti” általános iskola, több faluban müködő orvos, állatorvos stb.), de ezzel nem emelik székhelyüket várossá. Magyarország aprófalvas vidékein, pl. Zala, Vas, Baranya megyében néhányszáz 
Beluszky Pál - Győri Róbert : Fel is út, le is út... (Városaink településhierarchiában elfoglalt

pozícióinak változásai a 20. században.) Tér és Társadalom 18. évf. 2004/1. 1-41. p.

2 Beluszky Pál-Györi Róbert

TÉT XVIII. évf. 2004

lelkes kisfalvak intézményei is „,vonzásterületre” tesznek szert, „központok” lehetnek, de nem városok.

Az egyes tevékenységek, intézmények ,városképző” szerepe koronként változhatváltozik, elterjedtségének, gyakoriságának függvényében. A középkorban mindenfajta iskola városi funkciónak számított; a dualizmus korától a 20. század elejéig mindössze két egyetem müködött - Budapesten és Kolozsvárott -, vagyis országos szerepkörü intézmények voltak, mára viszont a regionális szint „alá” süllyedtek. Az elmúlt másfél évtized látványos példája az autókereskedelem hierarchikus rangjának inflálódása: az 1980-as években még országos funkciót jelentett, mára viszont kisvárosi funkcióvá szerényült.

A város, mint a földrajzi munkamegosztás terméke, városi javakkal látja el vonzáskörzete lakóit is. A vonzásterület, a ,piackörzet” tehát a városi szerepkör „,velejárója”, ám speciális településhálózat esetén, mint pl. a Nagyalföldön markáns vonzáskörzetek, legalábbis a közigazgatási határokon túlterjedő vonzáskörzetek nem alakultak ki. A települések város volta nem párosul szükségszerüen markáns vonzáskörzetek kialakulásával, jelenlétével, a város fogalma nem köthetỏ a vonzáskörzetek jelenlétéhez, hierarchikus pozíciója, városi szerepkörének súlya vonzáskörzetének nagyságához. Ezt azért kell hangsúlyoznunk, mert egyes vizsgálatok épp a piackörzetek kiterjedésével, nagyságával, ill. a városoknak a „vidék” ellátásában játszott szerepével „mérik” a városok hierarchikus pozícióját. (Így járt el „klasszikus" tanulmányában a geográfus W. Christaller, magyarországi vizsgálatai során Major Jenő vagy Gál Zoltán, a történészek közül pedig Bácskai Vera-Nagy Lajos.)

A városok településhálózati szerepköréből, a városok-falvak közötti munkamegosztásból következik a városoknak a cserében játszott kiemelkedő szerepe; a városok s a „vidék" javainak cseréje jórészt a városokban zajlik, de az eltérö termelést folytató „vidékek” cseréje is a városokba koncentrálódik, legalábbis a gazdaság magasabb fejlettségi fokán. Már a geográfia megteremtőjeként számon tartott Strabon szerint is a város ,... az a hely, ahonnan kiindulva és ahová érkezve az emberek nem csupán egymással érintkeznek, hanem a külvilággal is" (idézi Pounds 1997). Hasonló véleményeket hosszan sorolhatnánk; közülük csupán L. Mumfordra hivatkozunk: „A város voltaképpen már eredetétől fogva olyan struktúraként jellemezhető, amely kiválóan alkalmas a civilizáció javainak tárolására és közvetítésére, átadására...." (Mumford 1985) - s a ,városvédő” B. Oudint idézzük, aki szerint a „....keveredés, csere - ezen a ponton érintjük a város zsenijét” (Oudin én.). ${ }^{2}$

Természetesen a városnak a csere kitüntetett színtereként, a településhálózat központi szerepkörü tagjaként való meghatározása csupán a városok „géniuszának" lecsupaszított vázát tükrözi. Erre a „vázra” egy sor járulékos jegy rakódik, figyelembevételük hozzájárul a városokról formálható kép gazdagításához. A városok sokrétü funkcióinak müködtetése jelentős munkaerỏigénnyel jár: a város vonzást gyakorol környezetének lakosságára (migrációs központ), lakossága növekszik, lélekszámára nézve kiemelkedik környezetéböl. A városi intézmények müködtetése magasabb szintủ szaktudást igényel; a városi társadalmak nemcsak népesebbek a falusiaknál, hanem eltérö a foglalkozási szerkezetük, képzettségük, iskolázottságuk. 
Beluszky Pál - Győri Róbert : Fel is út, le is út... (Városaink településhierarchiában elfoglalt pozícióinak változásai a 20. században.) Tér és Társadalom 18. évf. 2004/1. 1-41. p.

Ennek, valamint számos más tényezőnek a hatására - pl. eltérỏ müvi környezet, a kiváltságos helyzet, a „tömeg-létböl” fakadó szociálpszichológiai hatások stb. - jellegzetes városi életmód, értékrend, életstílus, szociálpszichikai viselkedésmód alakul ki a városok falai között. A mủvi környezet, az infrastruktúra - már csak a nagy népességtömörülésből fakadó igények miatt is - ugyancsak eltérő a falusi településekétől.

A városok e sokoldalúsága, sokrétü „mássága”, ill. a puszta településhálózati szerepkörön felülemelkedő jellegzetességek késztették a városokról gondolkodókat újabb és újabb, a városok ,lelkéhez-géniuszához" közelebb férkőző megállapításokra, meghatározásokra ${ }^{3}$

Ám pusztán a városok „materiális” összetevői is bonyolult rendszert alkotnak; ez lehetővé-szükségessé teszi a sokirányú megközelítést, vizsgálatot, ugyanakkor a világosan és egyértelmúen meg nem fogalmazott kutatási célkitüzések esetén a vizsgálati szempontok összemosódásához, értelmezhetetlen eredményhez vezethetnek. Hibás az a vélekedés, hogy a korszerü matematikai-statisztikai módszerek mint pl. a faktor-és klaszteranalízis - birtokában megengedhető a rendelkezésünkre álló adatok szelektálatlan tömegének bevonása a vizsgálatokba, rábízván az alkalmazott eljárásra ezt a kutatói feladatot.

A településeknek az 1. ábrán feltüntetett alkotóelemeiböl kiindulva felvázolhatjuk a városföldrajz fỏbb vizsgálati terrénumait:

- Mint város-definíciónkban megfogalmaztuk, a központi szerepkör megléte, bizonyos mennyiségének és választékának elöfordulása emel egy települést várossá, hívja létre azokat a településközi kapcsolatokat, viszonyokat, amelyek az adott város településhálózati szerepét meghatározzák. A településhálózati szerepkört első renden a városhierarchiában elfoglalt helyzet határozza meg. Ennek kimutatása a központi funkciójú intézmények, tevékenységek számbavételén alapul, mindenekelőtt a kínált választék figyelembevételével.

- A településhálózatban elfoglalt helyzet más aspektusaira mutat rá a városi funkciók súlyának, volumenének számbavétele, e funkciók városon belüli jelentőségének, szerepének vizsgálata - amit pl. az 1000 lakosra jutó kórházi ágyszámmal, középiskolai tanulóval, a kiskereskedelmi boltok alapterületével stb. fejezhetünk ki -, ami már átvezet a városok funkcionális típusainak vizsgálatához. Kimutatható a városi szolgáltatások vidékre jutó hányada (W. Christaller szóhasználatával élve jelentőségtöbblete), ill. a vonzáskörzet nagysága (ám ez utóbbi nem áll egyenes arányban a hierarchikus szinttel, a városnak a településhálózatban betöltött szerepével.)

- A funkciók településen belüli ágazati arányai (a funkciók közé sorolva a lakófunkcióit is!) jelölik ki a városok funkcionális típusait (pl. gyáripari város, kikötőváros, üdülötelepülés, adminisztrativ-kulturális központ stb.). Az egyes funkció-csoportok, ágazatok településen belüli súlyának összehasonlítására többnyire a lakosság foglalkozási szerkezetét használják. 
Beluszky Pál - Győri Róbert : Fel is út, le is út... (Városaink településhierarchiában elfoglalt pozícióinak változásai a 20. században.) Tér és Társadalom 18. évf. 2004/1. 1-41. p.

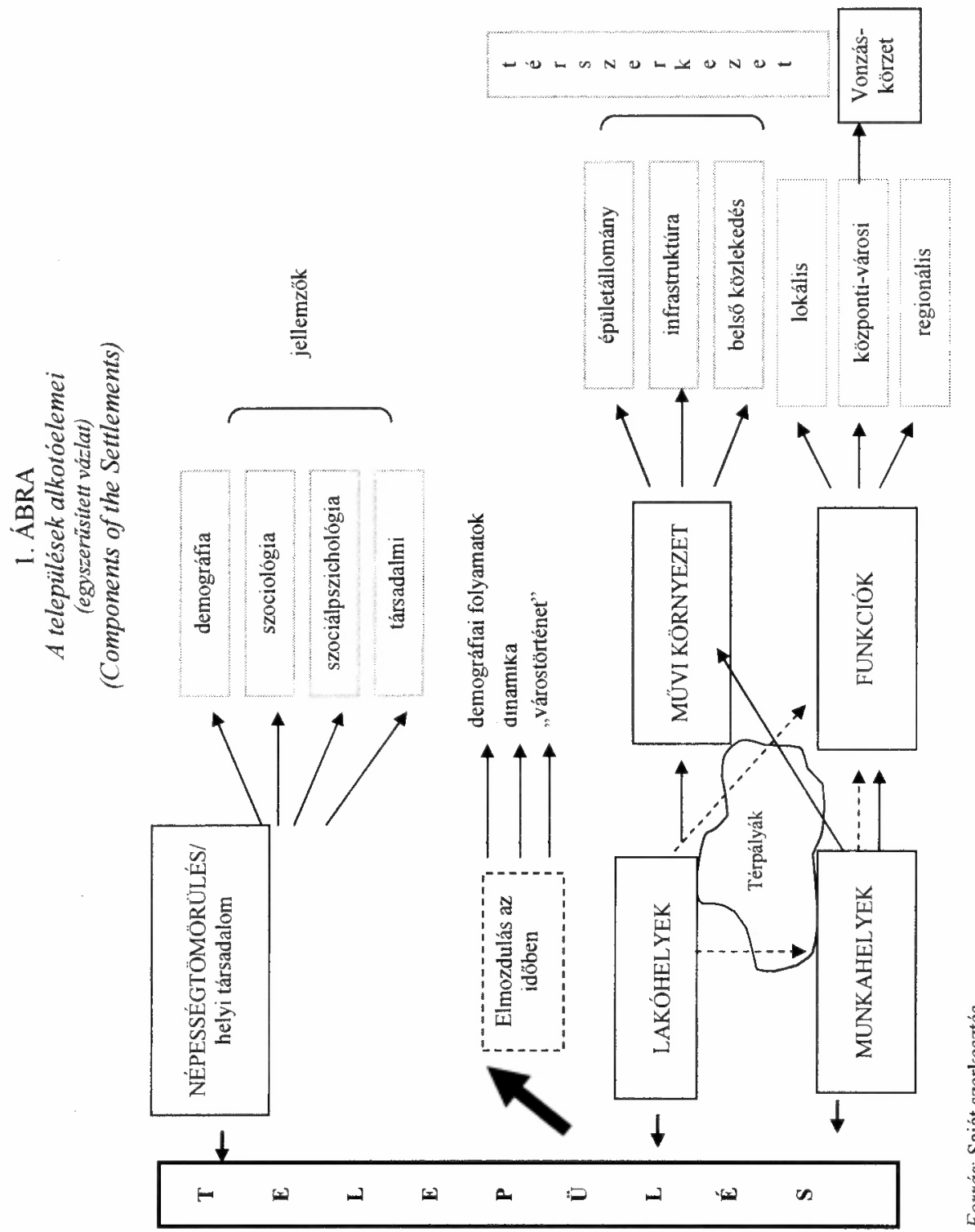


Beluszky Pál - Győri Róbert : Fel is út, le is út... (Városaink településhierarchiában elfoglalt pozícióinak változásai a 20. században.) Tér és Társadalom 18. évf. 2004/1. 1-41. p.

Fel is út, le is út ...

- Az elmúlt évtizedekben a településekkel foglalkozó tudományok - telepuilésstatisztika, településtudomány, városföldrajz, városszociológia stb. - körében nagyszámú vizsgálat célozta a fejlettségi szint meghatározását. A településfejlettségi vizsgálatokban az az igény jut kifejezésre, hogy a települések valamennyi összetevője, tevékenysége összemérhető legyen. A legkülönbözőbb léptékü és jellegü tényezők - pl. intézményellátottság, közmủvesítettség, a lakásállomány mutatói, a lakosság múveltségi szintje, egészségi állapota, a településsel való elégedettség foka, a jövedelmi viszonyok és így tovább - összemérésének talán egyetlen lehetösége kínálkozik abban, ha feltételezzük: e tényezőknek létezik egy optimuma (vagy maximum-értéke), s változásuk, „fejlổésuik” ezen érték felé halad. E „fejlettségi skálákon” a városok legkülönbözőbb összetevőinek helyzete kijelölhetö - pl. az adott állományon belüli rangszámmal -, s ezen értékek valamilyen módszerrel összegezhetỏek, kialakítható akár egyetlen fejlettségi mutatószám (pl. a rangsorszámok átlagértéke).

- A város változó rendszer; az elmozdulás üteme és iránya alapján kijelölhetők dinamikai típusai, a modernizációhoz való viszonyuk, várostörténeti jellemzöik.

- A város méretére, funkciói súlyára, jelentőségére vonatkozó „,mutatók” alapján - pl. lakosságszám, munkahelyek száma, az intézmények volumen-adatai (pl. kórházi ágyszámok, középiskolás tanulók száma stb.), a lakásállomány nagysága, a beruházások értékei stb. - meghatározható a településállományon belül elfoglalt „súly”, ami természetszerủleg nem azonos a településhálózatban elfoglalt helyzettel, amely a központi funkciók fejlettségének, jellegzetességeinek alapján jelölhető ki.

- Végül a fenti szempontok alapján (esetleg kiegészülve pl. a regionális helyzettel, városesztétikai szempontokkal stb.) kijelölhetők a városok általános (komplex) típusai (a meglehetősen eltérő jellegủ, jelentőségủ szempontok összevetésének problémáitól most eltekintuink). Ehhez az ,alapkoordinátákat”, véleményünk szerint, a településhálózatban elfoglalt helyzet (hierarchikus szint, a központi funkciók további jellemzői) és az ellátott funkciók „szerkezete” adja.

- Nem részletezve napjaink divatos témáit, mint pl. a városok versenyképességének, innovációs képességének, modernizációs hajlandóságainak, „sikerességének" vizsgálata, nyilvánvaló a városvizsgálatok lehetséges sokfélesége. A városvizsgálatok célkitüzésének pontos körülhatárolása a vizsgálatok sikerének elengedhetetlen feltétele ${ }^{4}$.

Magunk a következókben az egyes magyarországi városok településhálózatban elfoglalt pozíciójának 20. századi változásait tekintjük át több idỏszakra - hosszú, kỏzép- és rövid távú változások - vonatkozóan. A településhálózatban elfoglalt pozíció legegyértelmúbb meghatározója a városhierarchiában elfoglalt hely(ezés), illetve a városi funkciók mennyisége, a vidék ellátásában részt vevö hányada és a város nagyságához mért súlya (,fajlagos” értékei). 
Beluszky Pál - Győri Róbert : Fel is út, le is út... (Városaink településhierarchiában elfoglalt

pozícióinak változásai a 20. században.) Tér és Társadalom 18. évf. 2004/1. 1-41. p.

\section{Módszerek}

A városhierarchiában elfoglalt pozíciót a szúkebb értelemben vett városi funkciók összetétele, egyes szerepkörök, ill. e szerepköröket ellátó intézmények jelenléte vagy hiánya, a városi funkciók - mégpedig a hierarchikusan differenciált funkciókintézmények - választéka határozza meg.

E meghatározáshoz néhány kiegészítő megjegyzést kell füznünk:

- A tágan értelmezett szolgáltatások egyes szektoraiban - mint pl. oktatás, kereskedelem, közigazgatás, igazságszolgáltatás stb. - müködỏ intézmények is hierarchikusan tagoltak. Ezt a tagoltságot a „fenntartásukhoz” szuikséges lakosság minimális száma, igénybevételük gyakorisága, egyes esetekben nyilvánvaló egymásra-épültségük, esetleg szervezeti alá-fölérendeltségi viszonyaik határozzák meg ${ }^{5}$. E hierarchikus láncok „legalján” többnyire olyan intézmények állnak, amelyek igénybevétele gyakori, fenntartásukra falusi méretủ lakosságszám is elegendő (szatócsbolt, általános [elemi] iskola, háziorvos; de pl. a bíróságoknak ilyen ,falusi” szintủ intézményük nincs, ha csak a szabálysértési uigyekben eljáró önkormányzatokat vagy rendöri szerveket nem számítjuk az igazságszolgáltatás alsó szintjéhez). Ezeket az alapellátást nyújtó vagy más néven falusi intézmények közé sorolhatjuk. A városhierarchia vizsgálatakor a ritkábban jelentkező igényeket kielégítö, a hierarchikus láncolatok középsöfelsỏ szakaszán helyet foglaló intézményeket (,városi” intézményeket) kell figyelembe vennünk.

- Ebböl következik, hogy a több települést ellátó - tehát „,kỏzpontinak” tünő intézmények nem szükségszerüen városi intézmények; az aprófalvas térségekben kialakult ,centrum-falvak” központjai ugyan kisebb-nagyobb körzetuknek, mégsem városok.

- Az egyes intézmények hierarchikus értéke természetszerüleg idöröl idöre változhat; az újonnan jelentkező városi funkciók-intézmények többnyire fokozatosan szétterjednek az országban. Látványos példát szolgáltatott e folyamatra a közelmúltban - mint említettük - az autókereskedelem: a „szocialista korszakban” hosszú éveken át csak a fóvárosban „osztogatták” a kiutalt személygépkocsikat, majd egy-két nagyvárosban nyitott kirendeltséget az egyetlen autókereskedő cég, az állami kézben lévő MERKUR. Tehát az autókereskedelem országos, majd regionális funkció volt. A rendszerváltozás után rohamosan terjedni kezdtek az autókereskedések, s vizsgálatunk idején 118 településen múködtek márkakereskedések, a nagyobb telepiiléseken természetesen egyszerre több is. Vagyis bö egy évtized alatt az autókereskedelem országos, ill. regionális funkcióból kisvárosi szintủ funkcióvá vált. Nagyobb távon hasonló „pályát futottak be” pl. a gyógyszertárak, orvosok vagy akár az elemi iskolák is. Mindez természetesen hosszabb távon nehezíti a hierarchia-vizsgálatok eredményeinek az összehasonlítását. 
Beluszky Pál - Győri Róbert : Fel is út, le is út... (Városaink településhierarchiában elfoglalt pozícióinak változásai a 20. században.) Tér és Társadalom 18. évf. 2004/1. 1-41. p.

- A városhierarchia-vizsgálatoknál tehát nem egyszerủen számba vesszük az egy-egy településen található városi intézményeket, hanem hierarchiaszintenként tesszük ezt. Ugyanakkor az esetek többségében nem voltunk tekintettel az egyes telepuiléseken található azonos intézmények számára, ill. a városi szerepkörök volumenére, annak ellenére, hogy nyilvánvalóan van összefüggés a városi intézmények volumene - az azonos funkciót betöltỏ intézmények volumene! - és a település hierarchia-szintje között. Ha egy településen 1-2-3, a másikban több tucat ügyvéd dolgozik, akkor egyaránt ,ellátottnak” tekinthetók e téren, ám szinte bizonyos, hogy az egy városban dolgozó több tucat ügyvéd között több lesz a specialista, mint a néhány ügyvéddel rendelkezö településen, s ez már e „szolgáltatás” terén is jelenthet magasabb hierarchia-szintet.

- A városi funkciók-intézmények volumene azonban külön vizsgálatok tárgyát képezheti. Azonos hierarchia-szint mellett is eltérö lehet egyes városi funkciók mennyisége, s ez szintén befolyásolja egy-egy város településhálózati helyzetét; a városi intézmények volumene pl. szoros kapcsolatban áll a város vagy vonzáskörzete lélekszámával. Néhány középvárosunk hierarchikus rangját elsősorban nem „középvárosi” funkcióinak köszönheti, hanem tulajdonképpen ,nagyra nött" kisváros; népes vonzáskörzete nagy volumenú kisvárosi funkciók jelenlétét indokolja, s ez a tény emeli - a fent mondottak alapján - középvárosi szintre a települést. Ilyen tendencia figyelhetö meg pl. Kisvárda és Mátészalka esetében.

- A településhálózatban elfoglalt helyzetet a városhierarchia-szint, a városi funkciók volumene mellett természetesen egy sor egyéb tényezó is befolyásolja, mint pl. a forgalmi helyzet, a ,vidék” ellátásában játszott szerep, a bonyolult vonzáskörzeti rendszerben elfoglalt hely és így tovább.

- A városhierarchia-vizsgálat - a mondottak alapján - egy sor, a városokkal kapcsolatban felvetődő kérdésre természetszerüleg nem ad választ (a városok fejlettsége, típusai stb.). Csak közvetve kapcsolódik a hierarchia-vizsgálat az újabban gyakori ,versenyképesség”-vizsgálatokhoz, a „siker” alapján kialakított sorrendekhez, vagy a városok innovációs képességének meghatározásához, noha a rangsorok közötti összefüggések fontos részei e vizsgálatoknak. (Pl. milyen szerepe van a hierarchikus szintnek a versenyképesség alakulásában, a „sikerben”.)

A városhierarchia feltárására alkalmazott módszerek két alaptípusba sorolhatók:

A vizsgálatok egy részében nem kísérlik meg a városi funkciók részletezóbb számbavételét, hanem vagy a városi szerepkör valamely „,következményét” mérik, mint pl. Christaller, W. német geográfus az 1930-as években Dél-Németországban végzett vizsgálatai során, aki a telefonelöfizetők számában találta meg a „,központosultság" mérőszámát (Christaller 1933), vagy pedig valamely városi funkció terén kialakult hierarchikus rangsort „viszik át” a városi funkciók egészére, elkerülendő az egyes mutatók összegzésének nehézségeit. Így járt el pl. Major Jenő, aki a kiskereskedelmi szerepkör méröszámai alapján határozta meg a magyarországi városok rangsorát a hatvanas évek elején (Major 1964). De ide sorolandó Kubinyi Andrásnak a középkori magyarországi városhierarchia feltárására tett kísérlete is, aki az 
Beluszky Pál - Győri Róbert : Fel is út, le is út... (Városaink településhierarchiában elfoglalt

pozícióinak változásai a 20. században.) Tér és Társadalom 18. évf. 2004/1. 1-41. p.

8 Beluszky Pál-Györi Róbert

TÉT XVIII. évf. 2004

egyes településekböl a bécsi, ill. a krakkói egyetemre érkező hallgatók száma alapján mutatta ki a hierarchikus tagolódást (Kubinyi 1971). A hierarchia-vizsgálatok többsége viszont „tételesen” kívánja számba venni a városi intézmények jelenlétét, esetleg mennyiségi adataikat, mintegy leltározva a városi funkciókat.

Kétféle gyakorlat - ill. a mögötte álló elméleti megfontolás - alakult ki abban a tekintetben, hogy a hierarchia-szint a városokban található intézmények - meglétük, volumenük, hierarchikus szintjük stb. - alapján határozható-e meg, vagy a városi szolgáltatásoknak a „vidékre jutó" hányada alapján. Ez utóbbi felfogás, ill. eljárás abból indul ki, hogy a város a földrajzi munkamegosztásban a „vidék ellátója” szerepét játssza, településhálózati szerepe (hierarchikus rangja) tehát a vidéknek nyájtott szolgáltatások volumenével határozható meg ${ }^{6}$.

Ez az eljárás elméletileg is támadható: a város ,saját” lakosságszáma egész egyszerủen a vonzáskörzet része, éppen úgy, mint a közigazgatási határain kívül esö terület. Számos gyakorlati megfontolás is ellene szól: egy olyan országban, ahol a városhálózat szerveződési elvei eltérőek tájanként - mint pl. hazánkban az Alföld és a Dunántúl eltérỏ településszerkezetú területein -, ugyanolyan összetételúvolumenủ városi funkció, ,jelentőségtöbblete" eltérö?

A magyarországi városhierarchiát több időpontra is meghatároztuk, mindenkor az adott országhatárok között. E vizsgálatok közül jelen tanulmányunkban az 1910-es, 1965-ös, 1995-ös és a 2000-es vizsgálatok eredményeit vetettük össze egymással. Valamennyi esetben a városi funkciók-intézmények megléte-hiánya alapján jelöltük ki a települések helyét a hierarchiában, vagyis a "leltározó" módszert alkalmaztuk. A figyelembe vett intézmények száma 90-100 között mozgott. Ezen intézményeket nem tekintettük úgy, mintha ezek tennék ki egy-egy település (teljes) városi szerepkörét, hanem a lakmuszpapír szerepét szántuk nekik, feltételezvén, hogy jelenlétük jelzi a települések város-voltát, illetve hierarchia-szintjét. A kiválasztott mutatókat elöfordulásuk gyakorisága (,diszpenzációs értékük”) alapján hierarchikus szintekbe soroltuk. A hierarchikus szintek számát tapasztalati úton határoztuk meg; számuk valamennyi vizsgálat esetében hat volt:

- országos hatáskörủ intézmények,

- regionális hatáskörü intézmények,

- megyei hatáskörü intézmények,

- középvárosi intézmények,

- kisvárosi (járási hatáskörü) intézmények,

- mikrotérségi szintü - városi funkciójú! - intézmények.

A vizsgálat során megállapítottuk, hogy a települések az egyes hierarchia-szintek mutatóiból milyen mértékben részesednek; az egyes városok abba a legmagasabb szintbe kerültek besorolásra, amelyben még a mutatók legalább kétötödével rendelkeztek. A városi szerepkörủ települések csoportján belül - csakúgy, mint az intézmények körében - 6 hierarchia-szintet különböztettünk meg (föváros, regionális központok, megyeközpontok, közép- és kisvárosok, „városkezdemények”). A nyert eredményeket a 2-3. ábrák tartalmazzák. 
Beluszky Pál - Győri Róbert : Fel is út, le is út... (Városaink településhierarchiában elfoglalt pozícióinak változásai a 20. században.) Tér és Társadalom 18. évf. 2004/1. 1-41. p.

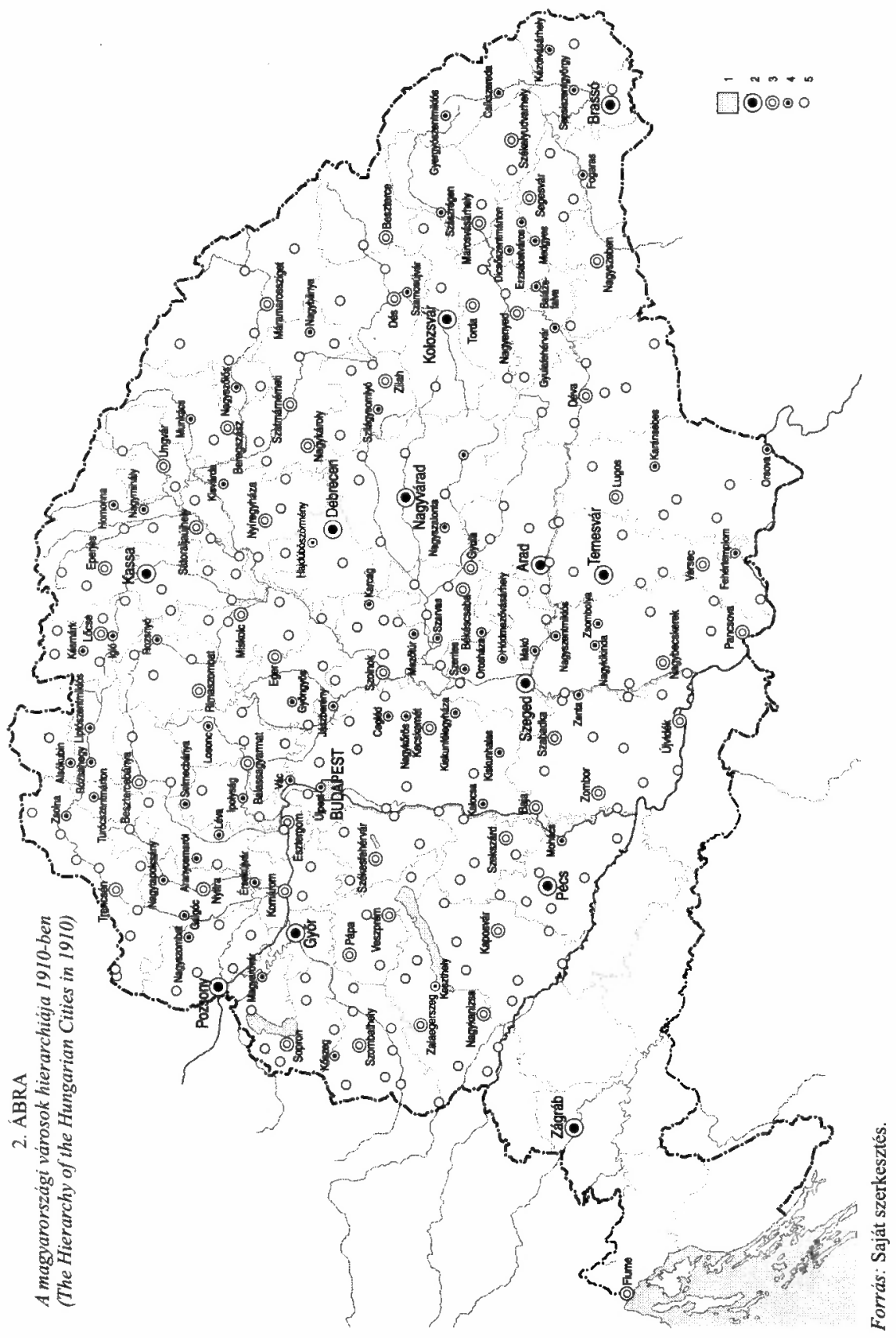


Beluszky Pál - Győri Róbert : Fel is út, le is út... (Városaink településhierarchiában elfoglalt pozícióinak változásai a 20. században.) Tér és Társadalom 18. évf. 2004/1. 1-41. p.

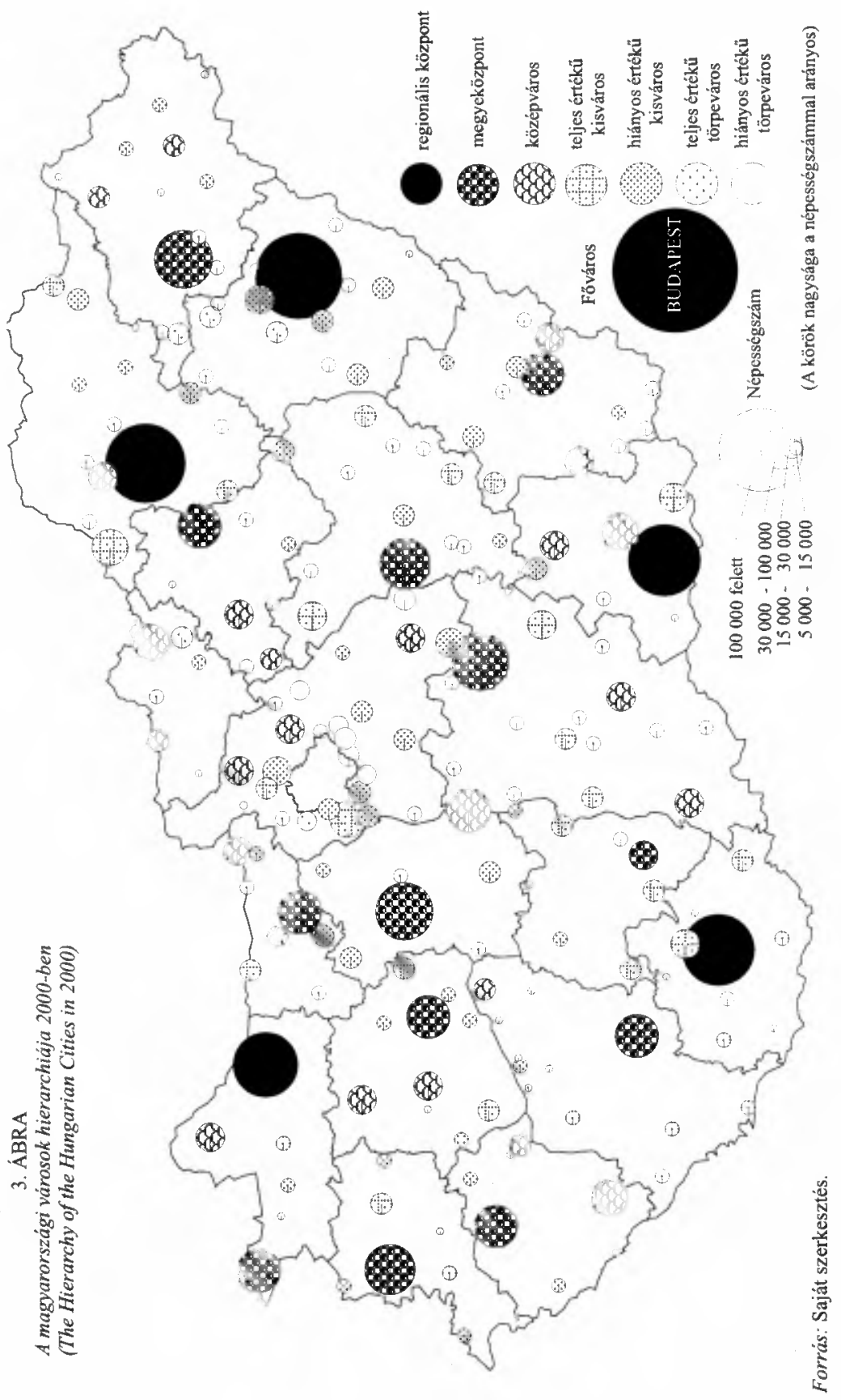


Beluszky Pál - Győri Róbert : Fel is út, le is út... (Városaink településhierarchiában elfoglalt pozícióinak változásai a 20. században.) Tér és Társadalom 18. évf. 2004/1. 1-41. p.

TÉT XVIII. évf. 2004 1

Fel is út, le is ut ...

A városhierarchia hosszú, közép-és rövid távú változásai

\section{Módszertani megjegyzések}

A több idöpontra végzett vizsgálatok szemlélete és az alkalmazott módszerek a lehetöségekhez mérten azonosak voltak; ez megkönnyítette a nyert eredmények összehasonlítását.

Ugyanakkor természetszerüleg teljesen azonos módon nem lehetett lefolytatni a vizsgálatokat, nem lehet teljesen azonos mutatórendszert kialakítani. A városi funkciójú intézmények az évtizedek során cserélődtek, a 20. század elejének egyes városi intézményei megszüntek, mások idöközben keletkeztek (pl. a müvese-állomások, vagy olyan hivatalok, mint a környezetvédelmi felügyelöségek). A többé-kevésbé azonosítható intézmények - pl. a gimnáziumok, a bíróságok stb. - településhálózati szerepe, elterjedtsége alapvetöen megváltozhatott. A középiskolák a 20. század elején még csak elvétve fordultak elö kisvárosokban, a középvárosi szintet jelezték, ma viszont már a kisvárosi szint alá ,süllyedtek”. A társadalomban betöltött szerepük is változott, így pl. az igénybevételük gyakorisága, az igénybevevők köre, társadalmi állása stb., arról nem is beszélve, hogy az időközben rendkívül differenciálttá váló középiskola-állomány figgyelembevétele a településhierarchia kialakításánál nem lehet azonos a korábbiakkal. Így tehát a különböző időpontokban végzett vizsgálatainkat azonos elvek-módszerek alapján folytattuk, de a statisztikai bázis változott, változott egyes intézmények társadalmi-településhálózati szerepe-helye is, ami a részletekbe menö, rigorózus összevetést nehezíti.

Természetesen lényegesen változott a városok szerepe a telepuiléshálózatban, a lakosság ellátásában, a társadalom szervezödésében. Az a tény, hogy pl. 1870-ben az akkori országterület lakosságának nem egészen 15\%-a élt városokban (pontosabban városi jogállású telepuléseken), 1910-ben 20,4\%-a, ma pedig kereken kétharmada, egymagában jelzi a városok merỏben eltérô szerepét a telepuiléshálózatban. Megváltozott a városok elérhetősége, a városi szolgáltatások igénybevételének lehetösége, gyakorisága, az igénybevevők köre. Több ízben változott a városok társadalmi „,képlete”. E változások természetesen messze túllépték a városhierarchia kereteit, illetve fogalomkörét, melynek a hierarchikus rangsorokban elfoglalt helyzetre való egyszerủsítése természetszerüleg csak a változások egyes aspektusait adja vissza.

A két szélső, vizsgált időpont (1910-2000) között két ízben is gyökeresen változott az ország társadalmi berendezkedése, a tulajdonviszonyok, a társadalom- és gazdaságszervezés mikéntje, a politikai berendezkedés, a közigazgatás stb. Mindez természetesen messzemenően kihatott a városfejlődésre, a városi élet szerveződésére, a városhierarchia alakulására; nehezíti pl. a piaci alapon - vagy legalábbis a részben piaci alapokon - szervezódó városhálózat és az adminisztratív módszerekkel szervezett-fejlesztett városhálózat összehasonlítását. Alapvetően megváltoztak a 
Beluszky Pál - Győri Róbert : Fel is út, le is út... (Városaink településhierarchiában elfoglalt

pozícióinak változásai a 20. században.) Tér és Társadalom 18. évf. 2004/1. 1-41. p.

városhálózat - $\mathrm{s}$ ennek elemeként a városhierarchia - szervezödési elvei a második világháború (illetve a „fordulat éve”) és a rendszerváltozás (1990) után ${ }^{8}$.

A nagytávú összehasonlításnál (1910-2000) figyelembe kell vennünk, hogy közben lezajlott hazánkban a „fordista típusú” iparosítás, a gyáripar, a bányászat, a tömegtermelés városokat hívott életre, pontosabban városi méretủ népességtömörüléseket, - mert nézetünk szerint az ipar nem számítható a szorosabb értelemben vett városi funkciókhoz -, melyek többsége aztán városi funkciókra is szert tett. A tömegipar, mivel telephelyei jórészt az energiaforrásokra és nyersanyaglelöhelyekre települttek, a meglévö településhálózattól függetlenül hozta létre a népességtömörüléseket, városokat, jelentős mértékben átrendezve a településhierarchiát (nemcsak „új” városokat teremtve, hanem a környező ,régieket” is sorvasztva, pl. Ajka Devecsert, Kazincbarcika Edelényt, Tiszaújváros Mezőcsátot stb.).

Az utóbbi két évtized viszont már Magyarországon is a "posztfordista" korszak beköszöntét jelentette, s e folyamat jóval gyorsabb volt, mint a legtöbb fejlett országban, mert a „természetes" technológiai-gazdasági folyamatok mellett hazánkban a piacgazdaság viszonyai között gazdaságtalannak bizonyult szocialista nagyvállalatok, ill. ágazatok - szénbányászat, uránérc-bányászat, kohászat stb. - gyors felszámolása, a KGST-piac összeomlása is közrejátszott a gyáripar területi és strukturális átalakulásához. Ennek következményei mára már a városhierarchia alakulásában is felismerhetök (pl. Ózd a „kisvárosok” közé ,süillyedt”).

Végül a (nagytávú) összehasonlításnál nem hagyható figyelmen kívül az országterület drasztikus mértékü megváltozása az első világháború után (Trianon); az államterület harmadára zsugorítása a mai határokon „belül maradt” városokon is sokrétü hatást gyakorolt, önmagában átrendeződésre kényszerítve az ország városhálózatát. (Nemcsak a határközeli városok vonzáskörzete csonkult, s indította el e városok ,sưlllyedését” - Balassagyarmat, Sátoraljaújhely, Sopron, Köszeg, Szentgotthárd, Barcs, Szeged stb. -, hanem a „,várostalanná" vált tájakon ösztönözte egyes települések „emelkedését” - Mátészalka, Berettyóújfalu, Baja stb. -, megváltoztatta Budapest pozícióját az országban, elszakította a legjelentösebb regionális központok Pozsony, Kassa, Kolozsvár, Temesvár, Nagyvárad stb. - többségét stb.).

\section{Hosszú távú változások}

A nagytávú változásokat (1910-2000) véve szemügyre, a városhálózat struktúrájában és az egyes hierarchikus szintekbe sorolt városállományban egyaránt szembeötlő a megórzés-változás egysége; a feltételek nagyarányú módosulását figyelembe véve hangsúlyoznunk kell a városhálózat viszonylagos állandóságát.

Ezt az állandóságot tủkrözi a városhierarchia alig módosuló struktúrája. Mind a négy időpontra egy hatfokozatú rendszer adta vissza a hierarchikus rangsor fö törésvonalait (1. fentebb). E hierarchikus tagolásnak lehetnek szubjektív elemei is, ám Budapest településhálózati helyzete (vitathatatlan elsősége, az országon beluuli s a városállományhoz mért kiemelkedő súlya, a mindenkori városi jellemzők hiánytalan megléte, az ország gazdasági, társadalmi, politikai életében játszott szerepe stb.) 
Beluszky Pál - Győri Róbert : Fel is út, le is út... (Városaink településhierarchiában elfoglalt pozícióinak változásai a 20. században.) Tér és Társadalom 18. évf. 2004/1. 1-41. p.

mindvégig egyértelmü volt. Minden időpontban egyértelmü volt néhány település kiemelkedése a megyeszékhelyek sorából; e városok országrésznyi területek városi javakkal való ellátását végezték (regionális központok) ${ }^{9}$.

Mindmáig „természetes” hierarchia-szint a megyeközpontok szintje is, különösen a polgári közigazgatás kialakítása óta, noha a polgári korszak kezdetén a megyeszékhelyek és a megyeközpontok hierarchikus szintjébe sorolt városok köre meglehetősen eltért egymástól. A polgári igazgatás kiépítésekor ugyanis jó néhány vármegyében egész egyszerüen hiányoztak azok a jelentösebb városi funkciỏkkal rendelkező települések, amelyekbe a megyei intézmények telepíthetök lettek volna, így egy sor alacsony hierarchia-szintủ település vált megyeszékhellyé, s a közigazgatási szerep mellé csak lassabban társultak a hierarchikus szintre jellemzö egyéb intézmények, ill. a városi lét, járulékos” jegyei, mint a magasabb lélekszám, városias településkép és infrastruktúra, nagyobb számú polgárság és így tovább (Alsókubin, Liptószentmiklós, Fogaras, Csíkszereda, Aranyosmarót, Ipolyság, Dicsőszentmárton stb.). A „szocialista korszak” végén viszont teljes volt az egybeesés a „megyeközpontok" és a megyeszékhelyek között, s az elmúlt tíz évben is csak Salgótarján hierarchikus helye kérdőjeleződött meg a megyeközpontok között, és Sopron „emelkedett” ez utóbbiak közé megyeszékhely-funkció nélkül.

Valójában csak a „,középvárosi" hierarchia-szint vitatható mind a 20. század elején, mind napjainkban.

E szintnek a magyar közigazgatási szisztémában nincs megfelelöje (nem volt a „szocialista korszak” településhálózat-fejlesztési koncepcióiban sem), a különféle igazgatási, állami intézmények telepítésénél is mellözték és mellözik a megyei és a ,jărási" szint közé esô hierarchikus fokozatot; napjainkban a funkciók e körében nem is található jellegzetesen e hierarchikus fokozathoz kötödő intézmény.

A kisvárosok (,járási székhely-szintủ központok”) ismét „természetes" elemei a településhierarchiának, létüket a közigazgatás területi rendszere is igazolta (és formálta is ezen szint állományát, intézményrendszerét), legalábbis 1984-ig - ekkor szüntették meg végérvényesen a járásokat -, illetve 1990-ig, a városkörnyékek megszüntéig. Ám az igazgatási, államszervezési, igazságszolgáltatási intézmények területi szervezetének kialakításában továbbra is kitüntetett szint a kisvárosok köre, a városi bíróságoktól az APEH-kirendeltségeken, földhivatalokon, rendörkapitányságokon át a tủzrendészeti feladatokat ellátó tüzoltóságokig. Legfeljebb ezen intézmények székhelyeinek száma csökkent, főleg az 1960-as, 1970-es évek járásösszevonásainak eredményeként. Természetesen az említett ,,igazgatási” funkciók mellett a piaci szférában vagy a kultúra-egészségügy területén is számos jellegzetes „,kisvárosi" intézmény mủködik (napjainkban a középiskoláktól az utazási irodákon át a kórházak belosztályáig).

A középvárosokhoz hasonlóan némi bizonytalanság a kisvárosi szint alatt mutatkozik. Az is nyilvánvaló, hogy a többé-kevésbé teljes körủ kisvárosi szolgáltatásokat nyújtó, a ,járulékos" városi jegyekkel - városi tradíció, városkép, népességszám stb. - rendelkező települések mellett léteznek olyan települések is, amelyek nem tekinthetők „komplett” városoknak ugyan, de rendelkeznek bizonyos városi intéz- 
Beluszky Pál - Győri Róbert : Fel is út, le is út... (Városaink településhierarchiában elfoglalt

pozícióinak változásai a 20. században.) Tér és Társadalom 18. évf. 2004/1. 1-41. p.

14 Beluszky Pál-Györi Róbert

TÉT XVIII. évf. 2004

ményekkel, szerepkörökkel. Így szükségesnek mutatkozik - s mutatkozott korábban is - egy hatodik, a kisváros „alatt” elhelyezkedő szint kijelölése. E hierarchikus fokozat esetében gondot inkább a falusi szint felé való elhatárolás jelent, mert kétségtelen, hogy a „városi minimum” meghatározása szubjektív megítélést is tükröz.

A településhierarchia viszonylagos stabilitását jelzi a városi funkciójú települések számának alakulása (1. táblázat). Különösen feltủnő az egyértelmúen városi funkciót ellátó települések - a föváros és az I-IV. fokozatba sorolt városok - számának állandósága: 1910-ben a jelenlegi országterületen 125 (Budapesttel együtt), a 2000. évi vizsgálat szerint 122 magasabb hierarchia-szintủ város létezett, igaz a hatvanas évekre vonatkozó vizsgálat ennél több, 142 „valódi” várost regisztrált.

\section{TÁBLÁZAT}

A városállomány hierarchikus tagolódása, 1910-2000

Az egyes hierarchia-szintekbe tartozó városok száma*

(Hierarchical Division of the Cities 1910-2000

Number of Cities in Each Hierarchical Level)

\begin{tabular}{lcccc}
\hline \multirow{2}{*}{ Hierarchia-szint } & \multicolumn{5}{c}{ Központok száma } \\
\cline { 2 - 5 } & 1910 & 1965 & 1995 & 2000 \\
\hline I. Regionális & 4 & 5 & 5 & 5 \\
$\quad$ központok & 20 & 12 & 14 & 13 \\
II. Megyeközpontok & 21 & 33 & 25 & 25 \\
III. Középvárosok & 79 & 91 & 83 & 78 \\
IV. Kisvárosok & 124 & 141 & 127 & 121 \\
I-IV. összesen & & & &
\end{tabular}

Forrás: Saját szerkesztés.

A regionális központok száma időközben Miskolccal gyarapodott; lényegesebben változott a megyeközpontok száma, 21-ről 13-ra csökkent. Ebben egyrészt a megyeszékhelyek számának csökkenése játszott szerepet; (1910-ben a mai országterületen 23 megyeszékhely funkcionált, 1922-1950 között pedig 25), másrészt az 1910-ben a megyeközpontok között szereplő, de megyeszékhely ranggal nem rendelkező városok - a közigazgatási „függés” növekedésével párhuzamosan - a középvárosok közé süllyedtek (Nagykanizsa, Pápa, Baja - ez utóbbi 1920-1950 között BácsBodrog megye székhelyének szerepét töltötte be). A közép- és kisvárosok száma 1910-hez viszonyítva alig változott, igaz, 1965-ben mindkét hierarchia-szinten némiképp emelkedett a központok száma.

Az egyes hierarchia-szintekbe sorolt városállomány változásait véve szemügyre, ugyancsak a változások és az állandóság egysége figyelhető meg. 1910-ben az akkori országterületen 10 város töltötte be a regionális központok szerepkörét (a *-gal jelzett települések regionális funkciói hiányosak):
1. Zágráb
6. Temesvár
2. Pozsony
7. Szeged*
3. Kolozsvár
8. Nagyvárad*
4. Kassa
9. Pécs*
5. Debrecen
10. Győr* 
Beluszky Pál - Győri Róbert : Fel is út, le is út... (Városaink településhierarchiában elfoglalt pozícióinak változásai a 20. században.) Tér és Társadalom 18. évf. 2004/1. 1-41. p.

További két város, Arad és Brassó pedig csak részben látta el a regionális funkciókat. Vagyis a jelenlegi öt regionális központunk közül négy már a 20. század elején is hasonló szerepet töltött be, csupán Miskolc „felzárkózása” esett a 20. századra; e folyamatot részben Kassa versenyének megszünése, részben a „szocialista korszak" Miskolcot támogató településpolitikája - Nagy-Miskolc kialakítása Diósgyőr s a környező községek hozzácsatolásával, egyetem alapítása, nagyarányú ipari és infrastrukturális beruházások stb. - indította el. (Miskolc egyébként már 1910-ben is a mai országterület 6-7. városa volt.)

A regionális központok kapcsán megjegyzendő, hogy mit sem változott e hierarchia-szint és a Budapest közötti „szakadék”. Nem igazolódott az a felfogás, hogy a fóváros „túlsúlya” kizárólag a trianoni határmegvonástól datálódik. Már a 20. század elején is a városi szolgáltatások igen magas hányada koncentrálódott Budapestre. Az ország lakosságának 4,8\%-át (1910) tömörítö föváros a városi funkciók arányára utaló „mutatókból” esetenként 20-62\%-kal részesedett (2. táblázat). Mindehhez járult, hogy a gazdasági életben, a kultúrában a fóváros „kliensi” viszonyba kényszerítette a ,vidéket”, ami a Budapesttel szembeni ellenérzések egyik forrása (a „,másság” mellett) ${ }^{10}$. Meglepö, hogy a regionális központok potenciális vonzáskörzeteinek nagysága (lélekszáma) alig változott egy évszázad alatt, átlagosan nem haladta-haladja meg az 1-1,2-1,5 millió föt, ami nem elegendő ,,igazi” nagyváros kialakulásához. (Igaz, egynémely egykori regionális központ potenciális vonzáskörzetében ma már ennél többen élnek.)

\section{TÁBLÁZAT}

Budapest részesedése néhány városi funkcióból, illetve arra utaló „mutatóból”, 1910 (Share of Budapest in Several Civic Functions, and in the Relating "Index", 1910)

\begin{tabular}{lc}
\hline \multicolumn{1}{c}{ Városi funkció, illetve mutató } & $\begin{array}{c}\text { Budapest részesedése az országos } \\
\text { értékböl, \% }\end{array}$ \\
\hline 1. Ingatlanokra felvett jelzálog & 61,3 \\
2. Egyetemi és föiskolai hallgatók száma & 61,9 \\
3. Banki töke & 60,0 \\
4. Napilap és folyóirat-kiadás & 47,3 \\
5. Kezdeményezett távbeszélgetések száma & 41,5 \\
6. Gyáripari dolgozók száma & 32,7 \\
7. Feladott táviratok száma & 26,4 \\
8. Kereskedelemból éló kereső & 23,3 \\
\hline
\end{tabular}

Forrás: Saját szerkesztés.

A regionális központok különböző időpontokban elfoglalt pozícióinak összevetése a hierarchikus jellemzők szívós továbbélésére utal. Miskolc a 20. század elején még csak a regionális központtá-válás küszöbére jutott, s hiába „szabadult meg” Kassa versenyétől, hiába ajnározták a szocialistának mondott érában, késését mindmáig nem tudta behozni. A Kisalföldön Györ gazdasági súlya egy sor regionális központét felülmúlta, adminisztratív-kulturális téren viszont nem vált „régiója” egyértelmü központjává, söt a regionális- és megyeközpontok között ingadozott (1900-ban vizsgálataink szerint nem is volt regionális központ), s a helyzet mindmáig alig változott. 
Beluszky Pál - Győri Róbert : Fel is út, le is út... (Városaink településhierarchiában elfoglalt

pozícióinak változásai a 20. században.) Tér és Társadalom 18. évf. 2004/1. 1-41. p.

A megyeközpontok körében látszólag a változás dominál: az 1910. évi 21 megyeközponttal szemben ma csak 13 város alkotja ezt a hierarchia-szintet. Ám az állandóságot jelzi, hogy a mai 19 megyeszékhelyünk közül 4 a századelön regionális, további 12 megyeközpont volt (közülük Kecskemét és Békéscsaba úgy, hogy akkor még nem töltött be megyeszékhely-funkciót), csupán Salgótarján és Tatabánya pályája emelkedett meredeken a szocialista érában, ekkor nevezték ki őket megyeszékhellyé, s igyekeztek városi szerepkörüket is kiépíteni. (Ez Salgótarján esetében mindmáig fél sikerrel járt: a hatvanas években még nem töltötte be a megyeközpont funkcióját, majd rövid „látogatás” után ma már ismét nem felel meg a megyeközpontok feladatainak.) Vagyis megyeközpontjaink többsége e szerepkör ellátásában nagy tradíciókkal rendelkezik, fontos ,kristályosodási pontokat” képeznek a magyarországi településhálózatban.

Ha a hosszú távú tendenciákat az 1910-es megyeközpontokra vonatkoztatva vizsgáljuk, kétségkívül a változások jelentösebbek, ugyanis 8 város (az. 1910-es megyeközpontok 43\%-a), kikerült ebböl a hierarchikus csoportból: Miskolc ,felemelkedett” a regionális központok közé, a többi alacsonyabb hierarchia-szintre süllyedt (4. ábra). Ezek:

- Nagykanizsa - 1910-ben, csak a mai országterületen található városokra vonatkoztatva, a 13. helyen,

- Sátoraljaújhely - a 14. helyen,

- Esztergom - a 17. helyen,

- Balassagyarmat - a 20. helyen,

- Gyula - a 22. helyen,

- Pápa - a 23. helyen,

- Baja - a 24. helyen állt.

E hét város közül a legnagyobb vesztes minden bizonnyal Sátoraljaújhely. A sülylyedése folyamatos: 1910-ben a mai országterület 14. városa, a hatvanas évek közepén a 36. - és ezzel a helyezéssel a középvárosok között foglalt helyet -, ma az 50-51., s egyértelmüen kisvárosi funkciókat lát el. A nagyfokú hanyatlás okai ismertek: mint hegyaljai város, már a szölötermelés, ill. a borkereskedelem 19. századi visszaesését, ill. a filoxéra-vész pusztításait megsínylette, ám népes megyéje igazgatási és kereskedelmi központjaként még látványos karriert futott be a dualizmus korában, lélekszáma 1870 és 1910 között megduplázódott, s elérte a 20 ezer föt. Az első világháború után megvont határok megyéje, igazgatási és gazdasági hinterlandja kétharmadától megfosztották, vasúti csomópontból helyi érdekü vasút végállomásává minősült vissza, maga s megmaradt vonzásterülete - a Bodrogköz, a Hegyköz - perifériává vált. A második világháború tovább rontott helyzetén: a háború végén közel 4 ezer fỏnyi zsidó lakosságát hurcolták el, ezzel az egyéni s kollektív tragédián túl a kereskedelemben, a kisiparban, a szolgáltatások terén, vagyis a városi funkciók terén is alig pótolható ür keletkezett, majd a megyeszékhely-szerepkör elvesztése (Zemplén megye beolvasztása Borsod-Abaúj-Zemplénbe) „végzetesen” hatott településhálózati helyzetére. Szükebb vonzásterülete is depreszsziós térséggé vált, a megye ipari beruházásai is elkerülték a várost és környékét. Ma környéke hátrányos helyzetü terület, a város hanyatlása szemmel látható: a nyilvánvaló hanyatlás, az általa generált rossz közérzet, letargia a térség konszolidálásának gátja. Sátoraljaújhely esetében a ,süllyedés” megállitása céljából indokolt lenne külsö területfejlesztési támogatás nyújtása a városnak. 
Beluszky Pál - Györi Róbert : Fel is út, le is út... (Városaink településhierarchiában elfoglalt pozícióinak változásai a 20. században.) Tér és Társadalom 18. évf. 2004/1. 1-41. p.

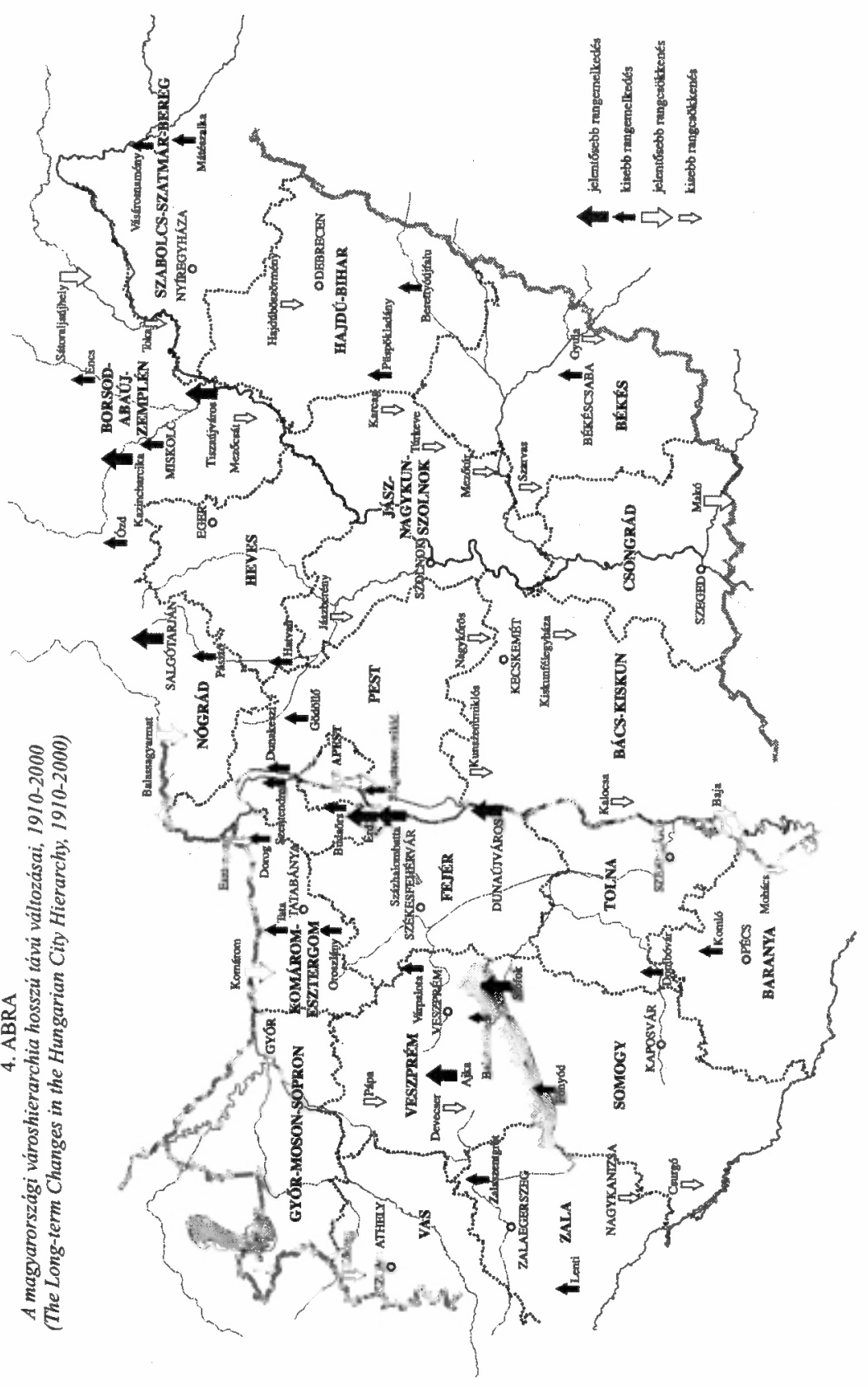

悹 
Beluszky Pál - Győri Róbert : Fel is út, le is út... (Városaink településhierarchiában elfoglalt

pozícióinak változásai a 20. században.) Tér és Társadalom 18. évf. 2004/1. 1-41. p.

18 Beluszky Pál-Györi Róbert

TÉT XVIII. évf. 2004 a 1

Balassagyarmat helyzete sok szempontból hasonlatos Sátoraljaújhelyéhez, igaz, a város sohasem volt Nógrád megye egyértelmü központja - gazdasági téren Losonc jelentösebb város volt -, nem is tartozott a megyeközpont szerepkört maradéktalanul ellátó városok közé, 1910-ben lélekszáma a Zemplén megyei székhely felét tette ki. Ám előbb a megye területének nagyfokú megcsonkítása, majd 1950-ben a megyeszékhely áthelyezése Salgótarjánba hasonló „eredményekkel” járt, mint Sátoraljaújhely esetében, igaz a városnak sikerült megkapaszkodnia a részleges középvárosok soraiban. Végső soron Esztergom is hasonló csapásokat volt kénytelen elviselni - a szocialista korszakban még mint klerikális város is bủnhödött, nem csak a megyeszékhelyet helyezték át Tatabányára, hanem teljesen ésszerütlenül a járási székhelyet is Dorogra -, ám fejlett oktatási-kulturális-egyházi-idegenforgalmi szerepköre, majd iparosodása „tartotta benne a lelket”, rövid távon javít is pozícióján, úgy hogy igazán nem sorolható a vesztesek közé (a rangsorban a 17. helyröl csupán a 20.-ra esett vissza, igaz, eközben egy hierarchikus lépcsövel lejjebb került). Sajátosan alakult Sopron helyzete; a századelön közvetlenül követte a rangsorban a regionális központokat, maga is rendelkezett regionális intézményekkel - az igazgatási típusú intézmények terén felül is múlta pl. Aradot és Brassót, hasonló pozícióra tett szert, mint Györ, ám a gazdasági tevékenység terén nem ütötte meg a regionális szintet -, az országos rangsorban (a mai országterületen) az 5. helyet foglalta el. Az első világháború után az Ausztriához füzödö kapcsolatok lazulása, megyéje egy részének elvesztése szintén érzékenyen érintette, ám az államvezetés „,hüségéért” a selmecbányai föiskola áttelepítésével, a város hathatós támogatásával jutalmazta. 1950-ben szintén elvesztette megyeszékhely rangját és feladatkörét, az osztrák határ közelében „holtsávba” került, s már a hatvanas években kikerült a megyeközpontok közül. A rendszerváltozás azonban ,rehabilitálta" a várost, addigi hátrányos forgalmi helyzete elönyére fordult, az ország legfontosabb nyugati kapuja, s ma az egyetlen nem megyeszékhely a megyeközpontok között; rövid távon javulnak pozíciói.

Az 1900-as évek elején a megyeközpontok között található, ám megyeszékhely ranggal nem rendelkező városok, Nagykanizsa, Pápa és Baja az említett okok következtében - az intézményszervezés-városfejlesztés és a közigazgatási pozíció szoros kapcsolata - már a hatvanas évekre a középvárosok közé kerültek. Helyzetüket rontotta, hogy megyeszékhelyeik riválist látva bennük, adminisztratív eszközökkel is gátolták városi szerepkörük megtartását-bövítését, pedig földrajzi helyzetük, településhálózati pozícióik lehetővé tennék sokoldalú városi szerepkörük ,gazdaságos" kiépítését. 1990 óta a megyék súlya, hatásköre, hatalmi pozíciója csökkent (az alig változó intézménytelepítési gyakorlat miatt a megyeszékhelyeké kevésbé). A kistérségi és a régió-szint igazgatási-szolgáltatási-területfejlesztési feladatainak további bövítése ösztönzöleg hathat a jelenleg megyei szintủ - s szorosan a megyeszékhelyekhez kötődö - intézmények telephelyválasztásának újragondolására; ,,megmozdul" az intézményi struktúra. (Minden ellenkezö ígérettel szemben feltehetöen tovább csökken a megyék igazgatási, területfejlesztési szerepe, esetleg létuik is megkérdőjeleződik.) Ezzel néhány „lesüllyedt” egykori megyeszékhely „,rehabilitációja” elött is megnyílhat az út; így pl. Baja számára, mely város a Bácska, sőt a kalocsai és 
Beluszky Pál - Győri Róbert : Fel is út, le is út... (Városaink településhierarchiában elfoglalt pozícióinak változásai a 20. században.) Tér és Társadalom 18. évf. 2004/1. 1-41. p.

a kiskunhalasi kistérség potenciális központja, s a „távoli” Kecskemét rovására növelheti városi szerepkörét, súlyát. Nagykanizsa is elönyösebb helyzetbe kerülhet a városversenyben Zalaegerszeggel szemben. De Pápa vagy Esztergom pozíciói is javulhatnak, ha nem is várható a megyeközponti hierarchia-szintbe való felemelkedésük.

A századelön a mai országterületen található középvárosokból, ill. a később e szintre süllyedö megyeközpontokból ma 16 található e hierarchia-szinten 9 újonnan felkapaszkodott város mellett, 1 I város viszont lesüllyedt e szintről. A középvárosok nagyobb „mozgékonysága” is igazolja e hierarchikus szint ,átmeneti” voltát, az „adekvát” közigazgatási rang stabilizáló hatásának hiányát. A középvárosok 1910 és 2000 közötti „,mozgását” a 3. táblázat foglalja össze.

\section{TÁBLÁZAT}

Az „1910-es” és a „2000-es” középvárosok pozíció-változásai a két idöpont között (Position Changes in the Middle Sized Cities between 1910 and 2000)

\begin{tabular}{|c|c|c|c|}
\hline $\begin{array}{c}\text { 1910-ben megye- } \\
\text { központok, ma } \\
\text { középvárosok }\end{array}$ & $\begin{array}{l}\text { Mindkét idöpont- } \\
\text { ban középvárosok }\end{array}$ & $\begin{array}{c}1910 \text { óta ,felemel- } \\
\text { kedett" középvá- } \\
\text { rosok }\end{array}$ & $\begin{array}{l}\text { 1910-ben még } \\
\text { középvárosok, } \\
\text { ma kisvárosok }\end{array}$ \\
\hline $\begin{array}{l}\text { 1. Nagykanizsa } \\
\text { 2. Esztergom } \\
\text { 3. Balassa- } \\
\text { gyarmat } \\
\text { 4. Gyula } \\
\text { 5. Pápa } \\
\text { 6. Baja }\end{array}$ & $\begin{array}{l}\text { 1. Vác } \\
\text { 2. Gyöngyös } \\
\text { 3. Szentes } \\
\text { 4. Keszthely } \\
\text { 5. Cegléd } \\
\text { 6. Hódmezövá- } \\
\text { sárhely } \\
\text { 7. Kisvárda } \\
\text { 8. Orosháza } \\
\text { 9. Kiskunhalas } \\
\text { 10. (Moson)- } \\
\text { magyaróvár }\end{array}$ & $\begin{array}{l}\text { 1. Salgótarján } \\
\text { 2. Dunaújváros } \\
\text { 3. Siófok } \\
\text { 4. Tata } \\
\text { 5. Hatvan } \\
\text { 6. Gödöllö } \\
\text { 7. Ajka } \\
\text { 8. Kazincbarcika } \\
\text { 9. Mátészalka }\end{array}$ & $\begin{array}{l}\text { 1. Makó } \\
\text { 2. Jászberény } \\
\text { 3. Mohács } \\
\text { 4. Kiskunfél- } \\
\text { egyháza } \\
\text { 5. Kalocsa } \\
\text { 6. Mezőtúr } \\
\text { 7. Szarvas } \\
\text { 8. Karcag } \\
\text { 9. Nagykőrös } \\
\text { 10. Hajdúbö- } \\
\text { szörmény } \\
\text { 11. Köszeg }\end{array}$ \\
\hline
\end{tabular}

Forrás: Saját szerkesztés.

Az 1910-ben vagy 2000-ben középvárosi szinten lévő városok közül különös figyelmet érdemelnek az 1910-ben még idetartozó, azóta viszont alacsonyabb szintre süllyedö városok. E 11 település közül 9 alföldi mezőváros, jelezvén, hogy a 20. század nem kedvezett az „alföldi úton” járó városoknak (az agrárkonjunktúra megszunnte, az ipar késői megjelenése, a vonzáskörzetek kialakításának nehézségei stb.). E „lesüllyedő” mezővárosok közül Makó, Jászberény és Kalocsa csak a legutolsó évtizedben került ki a középvárosok sorából, Nagykőrös és Kiskunfélegyháza pedig a „szocialista” érában. Különösen figyelemreméltó Makó „pályája”. 1910-ben már kiszorult a megyeközpontok közül, de 1950-ig megyeszékhely - az első világháború végéig Csanád, majd 1950-ig Csanád-Arad-Torontál vármegye szék 35 ezer lakosával az egyik legnépesebb középváros, a városi funkciók terén is éppen hogy lemaradt a megyeközponti szintröl; a hierarchikus rangsorban ekkor a 26. S noha megyei funkcióit 1950-ig örzi, sôt mezövárosi szerepkörében is „helytállt" - 
Beluszky Pál - Györi Róbert : Fel is út, le is út... (Városaink településhierarchiában elfoglalt pozícióinak változásai a 20. században.) Tér és Társadalom 18. évf. 2004/1. 1-41. p.

agrártermelését belterjesíti -, lélekszáma már ekkor csökkent, majd a kilencvenes években már középvárosi pozícióját is elvesztette (jelenleg a 49. a hierarchikus rangsorban). Ez utóbbi feltehetően kevéssé indokolt; igaz, az országhatár, Szeged, Hódmezővásárhely és Orosháza hinterlandját szük területre szorítja, forgalmi helyzete is hátrányos, ám a városi élet tradíciói, a kisvárosi szintet meghaladó lélekszáma indokolhatná középvárosi funkcióinak visszaszerzését. Jászberény is megsínyli a Jászság Szolnok felé fordulását, illetve Gyöngyösnek a Jászság északi településeire gyakorolt vonzó hatását. A ,jász identitás-tudat", a Jászság egészének Berény felé fordulása esetleg fenntarthatná a város magasabb hierarchia-szintjét. Mivel ma már a Jászság ,természetes” központjai közé számítódik Szolnok, Gyöngyös vagy akár Hatvan is, Jászberény , jogaiba való visszaállítása" nem nélkülözheti a tervszerüséget, a Jászság egészének közös akaratát.

$\mathrm{Az}$ alföldi mezővárosokon kívül csak Mohács és Köszeg került ki a középvárosi körből a 20. század folyamán. Mohács, a Duna fontos kikötője a 19. században még a Dél-Dunántúl egyik legfontosabb kereskedỏhelye. A vasúti hálózatban perifériára szorult, mindössze egy szárnyvonal fejállomása jutott a városnak; a dunai hajózás hanyatlásával párhuzamosan hanyatlottak a város központi funkciói is. Mivel a DélDunántúl városhálózatának egyik fogyatékossága a középvárosok hiánya - Baranya, Tolna és Somogy megyében csak Siófok lát el ilyen szerepkört -, mérlegelendö, hogy Mohács - hathatósabb támogatás esetén - elöbbre léphetne-e a hierarchikus rangsorban. (Pécs versenye erős!)

Köszeg lecsúszása a hierarchikus lejtön érthetö: a trianoni határ vonzáskörzetének javarészétöl megfosztotta, az országhatár és Szombathely között városi intézményei alig néhány községre kiterjedö hinterlandra tudtak szert tenni. Járási székhely funkcióit is korán elvesztette, ma a kistérségi funkciók egy részét is Szombathely látja el a város helyett. Ám az már elgondolkodtató, hogy napjainkban már az első 100 városba sem fér bele városi funkcióinak differenciáltsága-mennyisége alapján, a kilencvenes évek során is romlottak pozíciói (néhány év alatt a 85. helyröl a 114 . helyre szorult), s ma már olyan települések társaságában található a kisvárosok rangsorának végén, mint pl. Letenye, Kunszentmárton, Dunaföldvár, Sümeg vagy Gyomaendröd. Ami egyben a ,járulékos városi jegyek" - városkép, tradíció, vendégforgalom, a városi szolgáltatások kultúráltsága stb. -, s a szükebb értelemben vett városhierarchia esetenkénti meg-nem-felelésére is rámutat, $s$ hogy a városok ,rangjának” megítélésekor mily nagy szerepe van a „,külsőségeknek” (városfalak, müemlékek, „patina” stb.). (S felveti természetesen egy olyan vizsgálat szükségességét is, amely a városi funkciók „fejlettsége" mellett figyelembe venné a települések gazdasági jelentőségét és nemmateriális javait is, így állapítván meg az egyes városok „súlyát”.)

A középvárosi szintre „felemelkedö” városokat szinte kivétel nélkül a 20. század során kibontakozó „új” funkciók városfejlesztő energiája emelte e szintre: Salgótarjánt, Dunaújvárost, Ajkát, Kazincbarcikát a gyáripar és a nagyüzemi bányászat, Hatvant a vasút, Siófokot az idegenforgalom. Siófok mára nemcsak nagy forgalmú fürdővárossá vált, hanem kiépültek „szokványos” városi intézményei is, és Somogy megye északkeleti harmadának, a déli Balaton-partnak „valódi” városává vált. 
Beluszky Pál - Győri Róbert : Fel is út, le is út... (Városaink településhierarchiában elfoglalt pozícióinak változásai a 20. században.) Tér és Társadalom 18. évf. 2004/1. 1-41. p.

Gödöllöt részben az agglomerálódás, részben az a tény emelte a középvárosok közé, hogy egyeteme révén a magyar agrár-felsőoktatás és -kutatás központjává vált. Végül Mátészalkát a városok iránt mutatkozó „klasszikus” igény emelte a középvárosok közé, noha vizsgálatról vizsgálatra folyamatosan ,ingázott” a közép- és kisvárosok között. A századelön még egyike Szatmár megye kis piacközpontjainak, ám fokozatosan a környék vicinális vasútvonalainak csomópontjává vált (a két világháború között már 6 irányba futottak Mátészalkáról a vasútvonalak), majd a trianoni határmegvonás kevés „nyerteseinek” egyike: Szatmár-Ugocsa-Bereg megye központjává vált, „megszabadult” a korábbi megyeszékhely, a közeli Nagykároly versenyétől, városi intézményeit fejlesztik, megyei hivatalait kiépítik. S noha 1950-tól már nem megyeszékhely, egy ideig örzi megszerzett kedvezőbb pozícióit. Ám a környezö, határozott profilú kis központok hasonló jellegủ fejlesztése erös vetélytársakat támasztott Mátészalkának, elsősorban Fehérgyarmatot és Vásárosnaményt, de Csenger és Nyírbátor is korlátozzák vonzáskörzetét. Vissza is csúszott a kisvárosok közé Mátészalka a szocialista korszak végére, ám jelenleg ismét a középvárosok-kisvárosok határán található, pillanatnyilag épp „beférve” a középvárosok közé. Vảrosi szerepkörének megerösítése feltétlenül indokolt lenne: a megyeszékhelytől, Nyíregyházától messze fekvö, azzal csak igen laza kapcsolatban álló csengeri, fehérgyarmati, mátészalkai és vásárosnaményi kistérségnek szüksége van egy, a kisvárosi szint fölé emelkedő városi központra; ez az a területe az országnak, ahol egy középváros lehetséges vonzáskörzetén egy sor alacsonyabb hierarchiaszintü központ található.

Megjegyzendő, hogy sem a századelön, sem az ezredfordulón nem tartoztak a középvárosok közé Ózd, Komárom és Sátoraljaújhely, ám a köztes időben „tiszteletüket tették" e hierarchia-szinten: Sátoraljaújhely a megyeszékhelyek közül a középvárosokat érintve szállt alá a kisvárosok közé, Ózdot a gyáripar emelte a középvárosok közé, és ipari szerepkörének felszámolása nyomán került vissza a kisvárosok soraiba.

A két időpontot összehasonlítva a kisvárosokat is hasonló csoportokba oszthatjuk, mint a középvárosokat, annyi eltéréssel, hogy az 1910-es kisvárosi csoportból felfelé is vezettek utak (a fent említett Salgótarján, Tata, Hatvan, Gödöllö, Mátészalka). Az 1910-es kisvárosok közül 30 kirostálódott e hierarchia-szintröl ${ }^{1}$.

Közöttük már korántsem dominálnak az alföldi kismezővárosok, noha „,süllyedésük" folyamatos; az 1960-as évek óta vált ki a kisvárosok sorából Mezőcsát, Túrkeve, Nagykálló, Bácsalmás, a kilencvenes években Hajdúnánás. Az utóbbi eljelentéktelenedése elgondolkodtató; számottevỏ vonzáskörzete ugyan nincs - az egész Hajdúság Debrecen erős hatása alatt áll, ráadásul Böszörmény és Tiszavasvári közé szorítva legfeljebb Hajdúdorog városi javakkal való ellátásából vállalhat részt -, ám egynéhány kisvárosi funkcióra specializálódva, vagyis a hasonló nagyságú-funkciójú-városi rangú települések közt bizonyos munkamegosztást kialakítva talán fenntartható lenne kisvárosi szerepköre. (Ugyanez vonatkozik pl. a nagykunsági városokra is.) Az alföldi mezövárosok mellett elsősorban olyan egykori járási székhelyek estek ki a kisvárosi körbỏl, amelyek az igazgatási funkciók mellé nem tudtak számottevő egyéb városi funkciót is letelepíteni, viszont járási székhely 
Beluszky Pál - Győri Róbert : Fel is út, le is út... (Városaink településhierarchiában elfoglalt

pozícióinak változásai a 20. században.) Tér és Társadalom 18. évf. 2004/1. 1-41. p.

22 Beluszky Pál-Györi Róbert

TÉT XVIII. évf. 2004

rangjukat korán elvesztették (mint pl. Vál, Adony, Lengyeltóti, Sásd, Szentlörinc, Tab stb.). E csoportban is található néhány „,nagy vesztes”, pl. Abaújszántó, mely település a második világháborúig a Hegyalja élénk forgalmú kereskedőhelye, járási központ volt - s „teljes értékü” kisváros -, ma pedig városi szerepkörü intézményekkel már alig rendelkezik, s 2003-ig még a városi rangot sem „kapta meg” kárpótlásul. Devecser is elsorvadt Ajka mellett, ám mára „legalább" várossá vált.

Találunk a mai kisvárosok között mintegy tucatnyit, amely a századelön még semmiféle városi szerepkörrel nem rendelkezett. „Felemelkedésüket” három tényezönek köszönhették: ipari fejlesztésüknek (Ózd, Komló, Várpalota, Oroszlány, Dorog, Tiszaújváros, Százhalombatta), az agglomerációs fejlódésnek (Érd, Budaörs, Dunakeszi, Szigetszentmiklós) vagy az idegenforgalomnak (Balatonboglár, Fonyód).

E nagyarányú mozgás ellenére „tipikus” kisvárosaink többsége a 20. században mindvégig stabil tagja volt a kisvárosi körnek (Tapolca, Körmend, Bonyhád, Szigetvár, Kapuvár, Sárvár, Szerencs, Mór, Szentgotthárd, Berettyóújfalu stb.).

\section{Közép-és rövid távú változások}

A hatvanas évek elejétól napjainkig terjedő időszakban valamelyest csökkent az általunk kimutatott, funkcionális értelemben vett városok száma. A csökkenés elsösorban a közép- és a kisvárosokat érintette; az elöbbiek száma nyolccal (24\%), az utóbbiaké tizenhárommal (14\%) fogyatkozott meg, a teljes városállomány (a kisvárosokig bezárólag) húsz településsel. Mint említettük, pontosan azonos kritériumokat nem alkalmazhattunk a városállomány kijelölésére, tehát az eltérés ebböl is adódhat. De joggal feltételezhetö, hogy a középvárosok esetében a már vázolt folyamatok a felelösek a csökkenésért, a kisvárosok esetében pedig a hatvanashetvenes években végrehajtott járás-összevonások, egy sor járás megszüntetése, a jărási székhelyek meggyéritése. E folyamatot ebben az időben nem kísérte - kompenzálásként - a járási székhely-funkciójukat vesztett települések várossányilvánítása, így a térségi hatáskörủ intézmények is távoztak e településekböl (vagyis pl. a járásbíróságok nem alakultak át városi bíróságokká). Így azok az „elhagyott" járási székhelyek, amelyek nem rendelkeztek jelentékeny súlyú más, nem igazgatási jellegú funkciókkal, vagy egyéb ,megtartó” tényezővel - pl. nagy lélekszámmal -, kiestek a kisvárosi körböl. Számuk jóval nagyobb (33), mint a kisvárosok létszámfogyatkozása (,új”, felemelkedö települések is bövítették a kisvárosi kört, illetve a középvárosok létszámcsökkenése a kisvárosok körében természetesen növekedést eredményezett). Itt kell megjegyeznünk, hogy a kisvárosi szint alatt, a csekélyszámú városi intézménnyel, szerény városi funkciókkal rendelkező települések köre is erösen leszükült, noha a falvak-városok közti határ megvonása meglehetősen bizonytalan. A hatvanas évek első felére vonatkozó felmérésünk mintegy 150 ilyen települést mutatott ki, napjainkra viszont csak kb. 90-et (ha az akár egyetlen, általunk figyelembe vett, ,indikátorral" rendelkező településeket is figyelembe veszszük, akkor sem emelkedik e szám 120 fölé). Ennek magyarázata lehet a napjainkra alkalmazott mutatórendszer szigora (pl. a 2003-ban várossá-nyilvánított települé- 
Beluszky Pál - Győri Róbert : Fel is út, le is út... (Városaink településhierarchiában elfoglalt

pozícióinak változásai a 20. században.) Tér és Társadalom 18. évf. 2004/1. 1-41. p.

Fel is út, le is út ...

23

sekkel együtt ma 256 városi rangú település létezik; ez a szám több, mint az általunk kimutatott összes városi funkciójú település), de az is, hogy a szocialista korszak ellátási modellekben gondolkodó, koncentrációra törekvő településpolitikája az „elhagyott” kis központokból „kivonta” a városi intézményeket, és a városias funkciók ,államosítása" is a koncentrációt ösztönözte, így a korábbi központkezdemények, „elemi központok” jó néhány képviselője végleg kiesett a városállomány számbavételénél szóba jöhetô települések köréből. Így egy sor olyan települése van a magyarországi városállománynak, amely valaha szerény központi szerepkört töltött be, ma pedig már "belevész” a falvak sorába, mint pl. Mándok, Gáva, Szegvár, Kiszombor, Elek, Igal, Ricse, Gönc, Szendrö, Gyönk, Vajszló stb. Manapság, amikor a közigazgatás, a településfejlesztés és a városodás kapcsolata meglazult, ismét könnyebb „felkerülni” a városok körébe, s ezzel a lehetőséggel feltehetően élni is fog egynéhány település. Ugyanakkor időszerủnek látszik ismét „újraleltározni" a városi intézmények körét, ugyanis számos, korábban városinak számító szolgáltatás nagyszámú településen fellelhető ma már (kozmetikus, videotéka, ingatlanügynökség, panzió, szaküzletek stb.). Ezek esetleges figyelembevétele módosíthatja fenti megállapításainkat.

Az egyes hierarchikus szintek ,állományának” középtávú változásairól megállapítható:

A regionális központok sorában a századelöhöz képest változást jelentett Miskolc „felemelkedése” a regionális központok közé; a tradíciók nélküli regionális központ azonban „kiérleltségben”, minőségi jegyekben nem érte utol a tradicionális országrész-központokat, Pécset, Szegedet és Debrecent. A város a kilencvenes évek átmeneti „süllyedése” után napjainkra ismét felzárkózott a regionális központok teljes jogú tagjai közé.

Középtávon csekély változás mutatkozik a megyeközpontok sorában is. A kilencvenes évek folyamatainak eredményeként ismét e városok közt találjuk Sopront (napjainkban az egyetlen nem megyeszékhelyet a megyeközpontok között), noha természetesen a dualizmus-kori pozícióit nem sikerült visszaszereznie. Középtávon nem változott Salgótarján helyzete sem - akkor is, most is a középvárosok élén áltt, illetve áll -, ám közben mintegy negyed századon át megyeközponti funkciókat látott el, még a kilencvenes évek elején is tartotta ezt a pozícióját, csupán az utolsó 6-7 év versenyében bizonyult alkalmatlannak e szerepkör ellátására (lehet, hogy ismét csak átmenetileg).

A középvárosok gyérülése-pozícióvesztése, mely folyamatról a hosszú távú tendenciák ismertetésekor szóltunk, a második világháború után is folytatódott. Számuk a bö harminc év alatt nyolccal csökkent; a középvárosi szintröl kilépö települések száma - miután e szintre "felemelkedö” városok is előfordulnak - ennél természetesen nagyobb. A hatvanas éveket és a jelenlegi állapotot összevetve tíz városunk lépett ki „lefelé” e csoportból, közülük a következö hat, Nagykörös, Karcag, Mohács, Komárom, Sátoraljaújhely, Kiskunfélegyháza már a „szocialista korszakban”.

Mohács és Sátoraljaújhely viszontagságairól korábban már szóltunk; Sátoraljaújhely számára a középvárosi szint csak „megállónak” bizonyult a megyeközponti 
Beluszky Pál - Győri Róbert : Fel is út, le is út... (Városaink településhierarchiában elfoglalt

pozícióinak változásai a 20. században.) Tér és Társadalom 18. évf. 2004/1. 1-41. p.

szintröl a kisvárosok felé vezetó úton. Komárom „pályája” sajátos: a trianoni határmegvonásig csupán külvárosa-gyárvárosa és pályaudvara a túlparti megyeszékhelynek, törvényhatósági jogú városnak, Komáromnak. A Duna jobb partján lévő városrész a húszas években kezdte pótolni városi funkcióit, a rohamosan fejlődó iparvidék is támogatta növekedését; a hatvanas évekre a középvárosok közé került. A dezindusztrializáció azonban leértékelte az erös vetélytársak által kis hinterlandba zárt várost - Györ, Tatabánya, Tata, Esztergom versenye -, s már a kilencvenes évek elejére a kisvárosok közé került Komárom. Nagykörös, Karcag és Kiskunfélegyháza „alászállása” az alföldi mezővárosok meglehetősen általános hanyatlásának a része. Jászberény, Ózd, Kalocsa, Makó a kilencvenes években került a kisvárosok közé.

A hatvanas évek óta vált középvárossá Gödöllö, Ajka és Kazincbarcika, ez utóbbi kettő csak a közelmúltban. Gödöllö, mint már említettük, az agrároktatás és -kutatás révén került a középvárosok közé. Ajka és Kazincbarcika az ipari boom terméke, a hatvanas években még egyik város sem volt a „legjobb százban”. Mindkét város egyértelmủen „leküzdötte” a szomszédjában fekvő tradicionális kisvárost, Devecsert, illetve Edelényt, átvette szerepkörüket, $\mathrm{s}$ jelentös vonzáskörzetre tett szert, városi funkcióik mennyisége is tekintélyes; Kazincbarcika pl. az ország egyik legjelentösebb iskolavárosa, a középiskolai tanulók száma alapján felállított rangsorban a 26. A hatvanas években mind Kisvárda, mind pedig Mátészalka a középvárosok sorában található, s azóta a középvárosok-kisvárosok között húzódó zónában „ingáznak”.

A kisvárosok köre is számottevően változott negyven év alatt. A hatvanas évek kisvárosai közül 33 (az 1965-ös állomány 36\%-a) ma már alacsonyabb hierarchiaszinten található. Ebben közrejátszik az is, hogy a két vizsgálati időpont között a kisvárosok száma tizenhárommal csökkent. Azok az „alászállások”, amelyeket a hosszú távú változásoknál említettünk, többnyire ezekben az évtizedekben, tehát a „,szocialista korszakban” realizálódtak (ennek okait említettük). E „lesüllyedő” városok többsége a hatvanas-hetvenes-nyolcvanas évek áldozata (pl. Devecser [95 ranghely-visszesés], Szob [75], Sellye [70], Csurgó [67], Enying [66], Derecske [64], Abaújszántó [62], Pécsvárad [62], Putnok [58], Kunhegyes [57], Mezőcsát [55], Sásd [53], Biharkeresztes [51] stb.)

A kilencvenes években vesztette el kisvárosi funkcióját Kisbér, Vasvár, Edelény, Füzesabony, Szécsény, Kisújszállás és Hajdúnánás.

A listából kitűnik, hogy a járási székhely-rangjuknak köszönhetően „,központi helyekké", ám nem sokoldalú kisvárosokká váló települések kerültek ki elsősorban e hierarchia- szintből (Devecser, Szob, Sellye, Sásd, Biharkeresztes, Csenger stb.).

A hatvanas évek óta gyarapodott is a kisvárosi állomány, s a felemelkedés mögött - mint más hierarchiaszinteken és más időintervallumokban is - az erőteljes ipari fejlödés (Tiszaújváros, Oroszlány, Százhalombatta), az agglomerálódás (Érd, Szigetszentmiklós, Dunakeszi, Budaörs) és az üdülőhelyi fejlödés (Balatonboglár, Fonyód, Balatonalmádi) állt. Csak Letenye került, - a kilencvenes években - más „indokok” alapján a kisvárosok közé. 
Beluszky Pál - Györi Róbert : Fel is út, le is út... (Városaink településhierarchiában elfoglalt pozícióinak változásai a 20. században.) Tér és Társadalom 18. évf. 2004/1. 1-41. p.

Fel is út, le is út ...

De ezek az indokok ,mozgatják” felfelé a településeket a városiasodás alsó zónájában is. Gárdony és Balatonlelle a hatvanas években falusi funkciójú települések, ma már a ,jobb" kisközpontok közé tartoznak (a rangsor 143. és 148. helyén). Budakeszi, Kerepestarcsa, Dunaharaszti és Veresegyház a fővárosi agglomeráció részeként tett szert néhány városi intézményre. Bátonyterenye, Tiszavasvári és Martfï az iparosításnak köszönheti mindezt.

A rövid távú, a kilencvenes években bekövetkezett változások jeleznek ugyan figyelemre méltó tendenciákat, de a rendszerváltozás után eltelt rövid idö nem formálta át jelentösebb mértékben a városhierarchiát.

A regionális központok állománya, hierarchikus rangsora nem változott, de apró elmozdulások megfigyelhetők az elmúlt években is. Miskolc „hullámvasutazása” folytatódott: a szocialista érára eső felfutása után már a nyolcvanas években hullámvölgybe került a város - a nehézipar válsága, a munkanélküliség, a kiemelt központi támogatások elapadása, a gyors népességszám-csökkenés miatt -, ám a kilencvenes évek közepétől ismét felszálló ágba került. A város (némi meglepetésünkre) felzárkózott a teljes körü ellátást nyújtó regionális központok közé, annak ellenére, hogy a város gazdasága (ipara) nem revitalizálódott-modernizálódott számottevő mértékben. A város rehabilitációja a városi funkciók bỏvülésévelmodernizáció-jával vette kezdetét, ám felsőoktatási, tudományos, kulturális szerepköre szerényebb, mint a másik három regionális központnak.

Györ hosszú idő óta részben betölti a regionális központok feladatkörét, a vidéki városok rangsorában tartósan az ötödik helyet foglalja el. Azonban részben erös konkurensei - a 20. század elején Pozsony, Sopron, söt a viszonylag közeli Budapest és Bécs -, részben a regionális funkciók szétforgácsolódása - Sopron, Szombathely, sőt Székesfehérvár és Veszprém is betölt regionális funkciókat az Észak- és Közép-Dunántúlon - következtében mindig igen távol állt a „valódi” regionális központok funkcióitól. Ez különösen szembetủnö volt a felsőoktatás terén. Mindezt nem ellensúlyozta - legalábbis a városhálózatban elfoglalt hely megítélésekor - a város prosperáló gazdasága, a városi élet járulékos jegyeinek kétségtelen fejlettsége, a polgári lét feltételeinek magas nívója. Viszont az elmúlt évtizedben a város mégis szúkítette a szakadékot maga s a többi re gionális központ között, elsösorban a „piaci” szerveződésủ intézményhálózat - pé: z- és biztosítóintézetek, kereskedelem, gazdasági és lakossági szolgáltatások stb. - terén. A felsőoktatás, a tudományos kutatás, az egészségügy, az államigazgatás intézményei terén viszont a város továbbra is csak hiănyosan tölti be a regionális központok feladatait; a két „,szektor” meglehetösen eltérö utat jár, eltérő pozíciót fọł lal el a hierarchikus rangsorban.

A ,szocialista korszakban” meglehetősen un iormizált, zárt településcsoporttá váló megyeszékhelyek hierarchikus szintjének "fellazítására” - legalábbis elméletileg - megteremtödtek a feltételek a rendszerváltož́s után. Úgy tủnik, az elmúlt évtized kevés volt arra, hogy jelentősebben differenciál a ezt a városcsoportot, ám két mozzanat feltétlenül említést érdemel. Az egyik $S c$, ron nagyon indokolt rehabilitációjának elörehaladása. A város a 20. század elején 1 ég a mai országterület 6. városa volt, 
Beluszky Pál - Győri Róbert : Fel is út, le is út... (Városaink településhierarchiában elfoglalt

pozícióinak változásai a 20. században.) Tér és Társadalom 18. évf. 2004/1. 1-41. p.

több regionális szintủ funkcióval. Egy sor „csapás” után (trianoni határok, vonzáskörzete egy részének elvesztése, a megyeszékhely-szerepkör megszünte, határsáv stb.) a „Szocialista korszakban” a középvárosok közé süllyedt. Az utóbbi tíz évben viszont Győrhöz hasonlóan elsősorban a piaci alapon szervezödő intézményei révén - egyedüliként a nem megyeszékhelyek közül ,felkerült" a megyeközpontok közé.

Salgótarján egyike korai ipari településeinknek, 1910-ben járási székhely, s a „teljes értékü kisvárosok” között találta vizsgálatunk. „Trianonnal” „megszabadult” Losonc és Fülek versenyétől, gyáripara és bányászata tovább növekedett, végül 1950-ben áthelyezték a megyeszékhelyet is Balassagyarmatról a bányászvárosba. Ám a hatvanas évekre még nem fejlödött „valódi” megyeközponttá, a hetvenesnyolcvanas években viszont, ha részlegesen is, de betöltötte e hierarchia-szint feladatait. A szénbányászás megszünte, iparának leépülése, a kiemelt településfejlesztés elmaradása viszont mára hierarchikus rangját is "leszállította"; a kis hinterlanddal rendelkező, kedvezőtlen forgalmi helyzetü város piaci alapú városi funkcióinak modernizálására, kiépítésére máig nem volt képes. Ma a két hierarchiaszint között foglal helyet a város, miután - megyeszékhelyként - „hivatalból” továbbra is ellát néhány megyeközponti szerepkört.

A középvárosok száma a kilencvenes években már nem változott, jelenleg 25 város található e szinten; középtávon azonban (1965-2000 között) számuk 8 darabbal csökkent. A középvárosok egyötöde azonban kicserélödött. A napjainkra vonatkozó vizsgálat már nem találta e hierarchia-szinten Kalocsát, Ózdot, Makót, Jászberényt és Szentendrét. Szentendre hierarchikus pályája sajátos. A ,tipikus" kisvárost (1965-ös vizsgálatunk Szentendrét a hiányos szerepkörú kisvárosok között, a rangsor 99 . helyén találta) az agglomerációs folyamatok, a mértéktelenül felduzzadt turistaforgalom és Pest megye „székhely-keresése” (Szentendrére telepítették a megyei müvelödési házat, a múzeumi központot, könyvtárat) a középvárosok közé emelte a szocialista korszak végére, miközben a tipikusan kisvárosi funkciói is hiányosak voltak (mindenekelőtt egészségügyi téren). Mindezzel együtt a város a hierarchikus rangsorban ,feljött” a 33. helyre; úgy tünik azonban, hogy a kilencvenes években terjedő-bővülő ,új” funkciók - pénzügyi-üzleti szolgáltatások, kereskedelem - csak kis számban telepedtek Szentendrére, a turisták nem a városi szolgáltatásokat keresik a kisvárosban. Ózd „alászállását” már „,magyaráztuk”, Kalocsa, Makó és Jászberény az alföldi mezövárosok városi szerepkörének vontatott bővülése következtében került relatíve kedvezőtlen helyzetbe. Településhálózati helyzetük romlásához feltehetỏen az is hozzájárult, hogy gazdaságuk még nem heverte ki a rendszerváltozás okozta válságot. Településhálózati helyzetük egyébként nem indokolja egyértelmủen kisvárossá szerényülésuiket, különösen Jászberény esetében, hisz a város szükebb vonzáskörzetében is kb. 80-82 ezren élnek - valamennyien az egykori Jászság településein -, s ehhez még 20-22 ezres peremzóna járul. A középvárosok körén belül is megfigyelhető néhány elmozdulás: Baja valamelyest visszaesett a rangsorban, ami azért feltủnö, mert a város és vonzáskörzete igen messze esik Kecskeméttöl, a megyeszékhelytől, s Baja potenciális vonzáskörzete akkora (Kalocsa, 
Beluszky Pál - Győri Róbert : Fel is út, le is út... (Városaink településhierarchiában elfoglalt

pozícióinak változásai a 20. században.) Tér és Társadalom 18. évf. 2004/1. 1-41. p.

TÉT XVIII. évf. 2004

Fel is út, le is út ...

27

Kiskunhalas és környékük is ide sorolható, ahol kb. 220 ezren élnek), hogy ekkora területre egyes megyei funkciók letelepedése is indokolt lenne. (Tolna megyében 250 ezren élnek, de Szekszárd vonzása alig terjed ki Dombóvár és Tamási kistérségére.) Vác is visszaesett némiképp, Tata, Hatvan és Pápa viszont javított helyezésén.

Valamelyest csökkent a legutóbbi időben a kisvárosok száma is. (1995-ben 83, jelenleg 77). Az ,elhagyott” adminisztratív központok (valamikori járási székhelyek) alászállása folytatódott, hacsak az igazgatási funkciók megfogyatkozását más szektorok városi intézményeinek súlya, vagy jelentős városi tradíciói ezt a folyamatot nem fékezték (mint az megtörtént pl. Köszeg vagy Szentgotthárd esetében).

Ilyen ,alapon” került ki a kisvárosok köréböl Edelény (helyzetét a közeli Kazincbarcika versenye is nehezíti), a Balassagyarmat és Salgótarján közé szorult Szécsény, a csak jelentéktelen vonzáskörzettel rendelkező, gazdaságilag is meglehetỏsen gyenge Vasvár, a városi tradíciókat nélkülözö, Eger árnyékában fekvő Füzesabony, valamint Ráckeve és Kisbér. Kunszentmiklós, Hajdúnánás és Kisújszállás településhálózati pozíciójának romlása a kicsiny, számottevő vonzáskörzettel nem rendelkező alföldi mezővárosok általános hanyatlásának képezi részét, Bátonyterenye pedig a lassan eltünő Zagyva-völgyi iparvidék meglehetősen funkciótlanná váló, tradíció nélküli „lakótelepeként” veszített jelentőségéből.

A kisvárosi szinten maradt, de romló pozíciójú városok többsége a Tiszántúlon található, jelezvén ezen országrész válságát. Feltünően „,visszaeső” kisváros pl. Berettyóújfalu, Tiszafüred, Nyírbátor, Vásárosnamény, a Duna-Tisza közén Kiskunfélegyháza. Feltünő, hogy Sárospatak hierarchikus helyezése is romlott. A területfejlesztésnek megkülönböztetett figyelmet kellene e településekre fordítani, mert a lefelé irányuló pályaív nehézzé teszi az „önerőből” való megkapaszkodást az adott szinten. Ráadásul a fenti kisvárosok jelentékeny vonzáskörzettel rendelkeznek, városi szerepkörük eljelentéktelenedése városhiányos térségek kialakulásához vezetne.

Az elmúlt évtizedben "felkerült" települések száma csekély, csupán Sümeg, Dunaföldvár és Letenye tartozik e csoportba. Letenye aprófalvas terület lokális központja, ahol a települések erösen rá vannak szorulva a központi szerepkörủ településekre (Lenti is érzékelhetően javított pozícióján a kilencvenes években), másrészt a határátkelö forgalma is hozzájárulhat a városi szerepkörök bövüléséhez. Sümeg és Dunaföldvár nagy hagyományokkal rendelkezỏ kisvárosok; úgy tünik, adminisztratív szerepük elvesztését, Dunaföldvár esetében Dunaújváros erős versenyét sikerült ellensúlyozniuk. A kisvárosok csoportján belüli előrelépést a már többször felsorolt tényezök indokolják: az agglomerációs fejlödés (Érd, Szigetszentmiklós, esetleg Nagykáta esetében), az idegenforgalom (Fonyód és Sárvár esetében, esetleg Siklós pozíciójavulásában) (5.ábra). 
Beluszky Pál - Győri Róbert : Fel is út, le is út... (Városaink településhierarchiában elfoglalt

pozícióinak változásai a 20. században.) Tér és Társadalom 18. évf. 2004/1. 1-41. p.

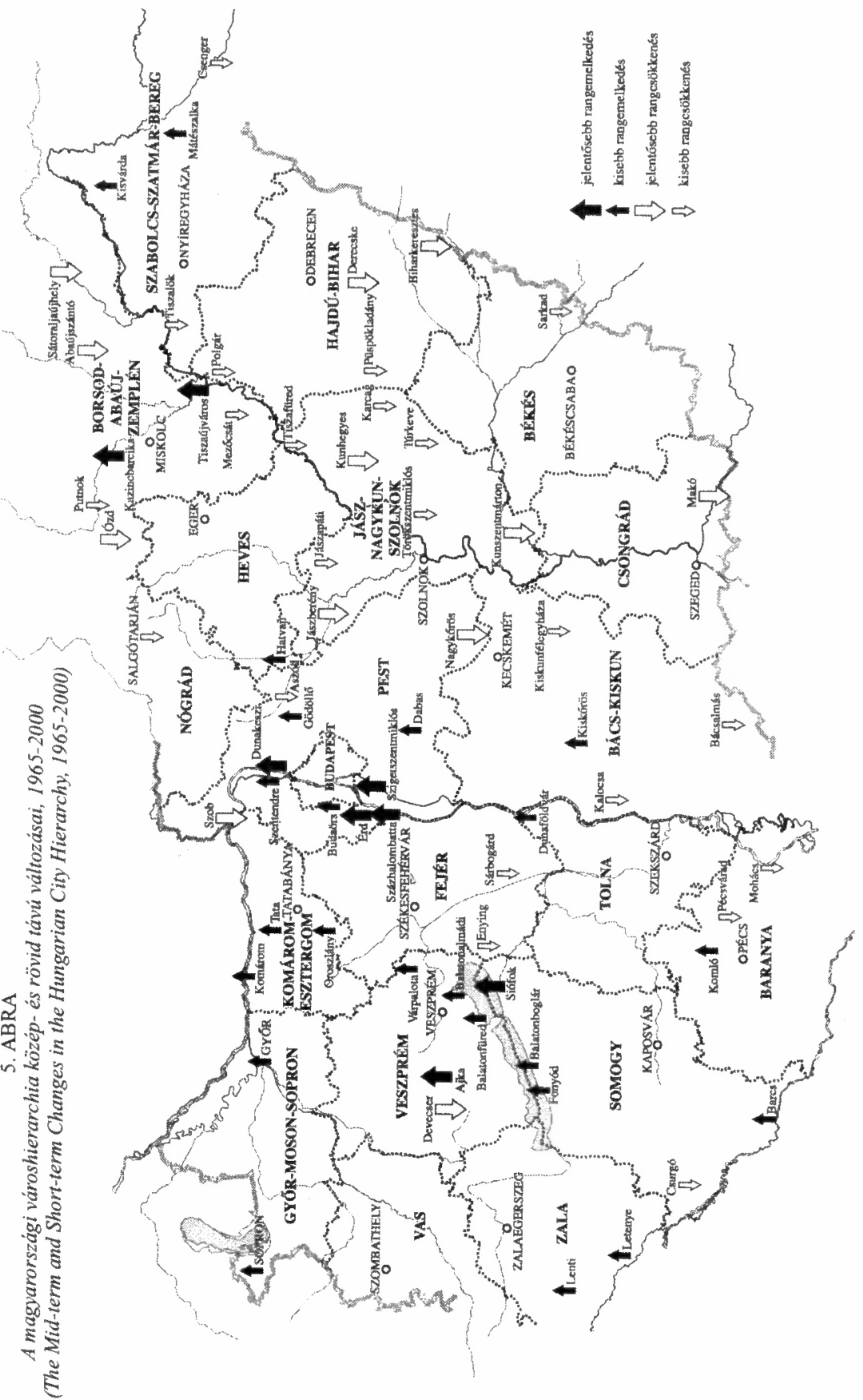

岕 
Beluszky Pál - Győri Róbert : Fel is út, le is út... (Városaink településhierarchiában elfoglalt

pozícióinak változásai a 20. században.) Tér és Társadalom 18. évf. 2004/1. 1-41. p.

TÉT XVIII. évf. 2004 ш 1

Fel is út, le is út ...

29

Változások az ellátott lakosság számában

(a városi funkciók mennyiségi elemzése)

Több szempontból vizsgáltuk az egyes városokban előforduló városi funkciók mennyiségi vonatkozásait is. Ugyanis - mint jeleztük - a szükebb értelemben vett hierarchia a városok településhálózati szerepének csak egyik aspektusát regisztrálja. Pl. az alföldi települések legtöbbjének magas hierarchikus rang esetén sincs kiterjedtebb vonzáskörzete, városi javaival elsősorban saját lakosságát látja el; tehát azonos hierarchikus pozíció esetén is igen eltérő lehet a városi szolgáltatások „vidékre eső hányada". Az 1910-es vizsgálatunkban tapasztaltuk, hogy a többékevésbé azonos szintü, súlyú városi funkciók az alföldi városok agrárszerepkörének tengerében szinte eltünnek, feloldódnak (az agrárvárosok város-volta is kérdésessé válik ezáltal), a tradicionális városok esetében viszont - különösen, ha azokba még nem települt számottevő gyáripar - „tisztán” jelentkeznek, hangsúlyos városi jelleget kölcsönözve e településeknek. Vagyis eltérö a városi funkciók ,sürüsége”. S noha a városhierarchiában elfoglalt pozíció $s$ a városi funkciók mennyisége között szoros korreláció mutatkozik, ám egyazon hierarchikus szinten belül is jelentösen eltérhet egymástól az egyes városok városi funkcióinak mennyisége, mert pl. a népes települések saját lakosságának ellátása megköveteli bizonyos intézmények megtöbbszöröződését, ám ez nem vezet közvetlenül a hierarchiaszint megemelkedéséhez. (Pl. népes városokban több polgári iskola is müködött, de ez nem javított a települések hierarchikus pozícióján az egy-egy polgári iskolával rendelkezö településekhez képest.) A városi funkciók minőségi összetétele mellett ezért vizsgáljuk a városi szolgáltatások mennyiségi adatait is. Ebböl ugyanis következtetni tudunk a szolgáltatásokat igénybe vevő népesség nagyságára, közvetve pedig az (elméleti) városi vonzáskörzetek kiterjedésére is. (A város és vidéke közti viszony feltárása a településhálózati kutatások egyik legfontosabb aspektusa. Egyes megközelítések szerint [(pl. Mendöl 1963]) alapvetően ez határozza meg a települések város voltát [a város mint „,központi hely”].)

A városi funkciók mennyiségi vonatkozásainak elemzéséhez az 1910-es vizsgálat során a következő mutatókat vettük figyelembe:

- A kereskedelemböl élö keresök száma (fö), 1910;

- A közszolgálati keresők száma (fö), 1910;

- A házicselédek száma (fö), 1910;

- Az ügyvédek száma (fö), 1910;

- A pénzintézetek bankbetétállománya (korona) 1909;

- A középiskolai tanulók száma (fö), 1910/1911;

- A telefonállomások száma, 1911.

A különbözö jellegủ mutatók - középiskolai tanuló, bankbetétállomány koronában, telefonállomások száma - összehasonlíthatósága-összegezhetösége érdekében kiszámítottuk a városi funkciók által ellátott lakosság számát. Ezt lehetővé teszi a kereskedelmi és közszolgálati keresők, a bankbetétek, ügyvédek stb. „egységnyi”" 
Beluszky Pál - Győri Róbert : Fel is út, le is út... (Városaink településhierarchiában elfoglalt

pozícióinak változásai a 20. században.) Tér és Társadalom 18. évf. 2004/1. 1-41. p.

TÉT XVIII. évf. 2004

lakosra jutó országos értékének ismerete, ill. ebből következően az egy kereskedö, házicseléd, ügyvéd vagy egy korona bankbetét által átlagosan ,kiszolgált” lakosok száma. 1910-ben pl. egy kereskedelemböl élö kereső által ellátott népesség száma országos átlagban 65,7 föt tett ki. Így a Pozsonyban 1910-ben tevékenykedő 3552 kereskedő által ellátott lakosság kereken 233 ezer före rúgott. Miután az egy före jutó bankbetétek országos átlaga 1909-ben 175,4 korona volt, Pozsony 70 millió koronát meghaladó betétállománya 401 ezer lakos pénzintézeti kiszolgálását valószínüsíti. A fenti értékekből a város lakosságszámát levonva megkapjuk az ellátott vidéki lakosság számát, a város ,jelentőségtöbbletét" (l. korábban), egyes geográfusok szerint a városhierarchia „valódi” mérőszámát. A fenti példa esetében ennek értéke 115 ezer kereskedelem által ellátott vidéki, illetve 323 ezer, a pénzügyi szolgáltatások terén ellátott lakos. A városi funkciók súlyának az ellátott lakosság számával való mérése lehetővé teszi az egyes szerepkörök, intézmények összevetését, illetve súlyuk megállapítását. Tulajdonképpen a vizsgálatot egyetlen mutatóval is elvégezhetjük, de a pontosabb eredmény érdekében több változóval dolgoztunk: a kiszámított „központ-vidék arányok” (az ellátott „vidéki" népesség és a város saját népességének hányadosa) átlagolásával érkeztünk el a végeredményhez: az egyes városok által ellátott összes és ,vidéki” lakosság számához. A mutatókat úgy választottuk ki, hogy azok a kisvárosi-középvárosi szerepkörök súlyát és a kisvárosi szintủ vonzáskörzetek nagyságát tárják fel, a teljes magyar városhálózat tagjai csak így hasonlíthatók össze. (Nyilván a városi funkciók súlyát nem mérik tökéletesen ezek a mutatók, inkább csak indikátorként jelzik a legfontosabb tendenciákat.) Ugyanezzel a módszerrel megkíséreltük a városi funkciók mennyiségi elemzését 2001 -es adatbázison is. Felhasznált mutatóink ekkor:

- kiskereskedelmi üzletek száma (db), 2001;

- járóbeteg szakellátás évi rendelési ideje (óra), 2001;

- nappali tagozatos középiskolai hallgatók száma (fö), 2001;

- társas vállalkozások száma (db), 2001.

Hangsúlyoznunk kell, hogy e számításokkal nyert különféle eredmények „képletes számok", nem a tényleges helyzetet tükrözik, pl. az ellátott vidéki lakosok száma nem azonos a városok vonzásterületének nagyságával, annak lakosságszámával. Ennek okai sokrétủek. Az egyes funkciók regionális elterjedtsége eltérhet az országos átlagtól; jobb kereskedelmi ellátottságnak örvendő területeken, pl. ugyanannyi kereskedö kevesebb lakost lát el, mint a gyéren ellátott területeken. (E hibalehetôséget csökkenteni lehetne regionális vagy megyei átlagértékek alapján történó számításokkal; ezzel ugyan reálisabban mérnénk egy-egy település saját környezetében, régiójában betöltött településhálózati szerepét, de rontanánk az országos öszszevetések pontosságát.) A városi szerepkörök, pontosabban az általunk figyelembevett „ágazatok” koncentrálódása vidékenként eltérő - nagyfalvas területen a „vidéki" települések is rendelkeznek több-kevesebb általunk figyelembevett intézménnyel, aprófalvas vidékeken viszont a kereskedelmi, közszolgálati, pénzintézeti stb. tevékenység túlnyomó többsége a városokba húzódik -, s a falvak is ellátnak bizonyos, általunk figyelembevett tevékenységeket. A városi funkciók igénybevé- 
Beluszky Pál - Győri Róbert : Fel is út, le is út... (Városaink településhierarchiában elfoglalt pozícióinak változásai a 20. században.) Tér és Társadalom 18. évf. 2004/1. 1-41. p.

telének gyakorisága a városokban élők részéröl magasabb, mint a vidékiek részéről, ahol az igények s a „vásárlóerő” is alacsonyabb, így az ellátott lakosság mechanikus szétosztása városira-vidékire a városok lakosságszáma alapján minden bizonnyal nem felelt meg a tényleges helyzetnek.

$\mathrm{Az}$ elemzés végeredményeként három újabb rangsort kaptunk: a városok által ellátott összes lakosság és „vidéki” lakosság nyomán kirajzolódó rangsorokat, illetve a „,központ-vidék arány” rangsorát; ezek összevetése egymással és a városhierarchiában elfoglalt hellyel érdekes tanulságokat tartogat. Az adatsorok közlése elött máris felhívjuk a figyelmet az egyik legfontosabb sajátosságra: az ellátott vidéki lakosság száma negatív (elméleti) értéket is felvehet: ez az jelenti, hogy az adott telepuilés saját lakosságát sem látta el teljes egészében városi javakkal (kimutatható vonzáskörzetuik ezeknek a városoknak nincsen; illetve a más városok által az illető településböl „elvonzott” lakosság - igénybevétel, vásárlóerő - nagyobb, mint a „bevonzott”). Ezen települések egy része mégis város lehet, amennyiben városi intézményeik vannak, és (legalább) saját lakosságuk számára nyújtják a városi lét előnyeit.

Első megközelítésként korrelációt számoltunk a városok népessége és a központvidék arány között. A számítással azt a feltevést szerettük volna igazolni (vagy cáfolni), mely szerint a népesebb városokhoz arányaiban is nagyobb vonzáskörzet tartozik. A korrelációszámítások eredménye (1910-ben $r=0,05 ; 2001$-ben $r=0,18$ ) azt mutatja, hogy nincs ilyen összefüggés, a markáns központi szerepkörú település mérettől független, mind a kisebb, mind a népesebb települések között találunk ilyeneket, 1910-ben Békéscsaba (42 ezer lakos) esetében az ellátott vidéki/saját lakosság aránya mindössze $22 \%$, míg ugyanez a hányados a 8200 fös Balassagyarmat esetében 400\%! A szélsöségek 2001-re is csak arányaiban enyhültek: Tatabányán (84 ezer lakos) az ellátott vidéki/saját lakosság aránya csak 16\%, a 15 ezer fös Fehérgyarmat esetében $168 \%$. A látszólagos ellentmondást csak részben magyarázza a hierarchiában elfoglalt pozíció, bár a városhierarchia mentén lefelé haladva viszont a csökkenés egyértelmú: az alacsonyabb hierarchia-szintú városok (átlagosan) kisebb központ-vidék aránnyal rendelkeznek (4. táblázat). A legnépesebb települések (25 ezer fö fölött) köre, ahol az elméletileg ellátott vidéki lakosság értéke negatív (nincs kimutatható vonzáskörzet) 1910 és 2001 között új típusokkal bővült. 1910-ben Hajdúböszörmény, Békés, Csongrád és Törökszentmiklós alkotta az „élbolyt”, 2001-ben viszont Érd, Ózd, Hajdúböszörmény, Orosháza, Komló és Nagykőrös a sorrend. Míg a múlt század elején szinte kizárólag alföldi, nagy határú, tanyás mezővárosok kerületek ide, ma a népes, vonzáskörzet nélküli települések három jól elkülöníthetô csoportra bonthatóak. Egyrészt ilyenek a budapesti agglomeráció felduzzadt népességü ,alvóvárosai” (Érd, Monor stb.), másrészt azok az alföldi (egykori) mezövárosok, amelyeknél a központi funkció soha nem vált jellegadóvá (a fentiek mellett: Karcag, Mezőtúr, Gyomaendrőd stb.), harmadrészt pedig az egyoldalúan ipari jellegú, funkcióhiányos „szocialista” városok (Ózd, Komló, Várpalota, Oroszlány stb.) (6. ábra). 
Beluszky Pál - Győri Róbert : Fel is út, le is út... (Városaink településhierarchiában elfoglalt pozícióinak változásai a 20. században.) Tér és Társadalom 18. évf. 2004/1. 1-41. p.

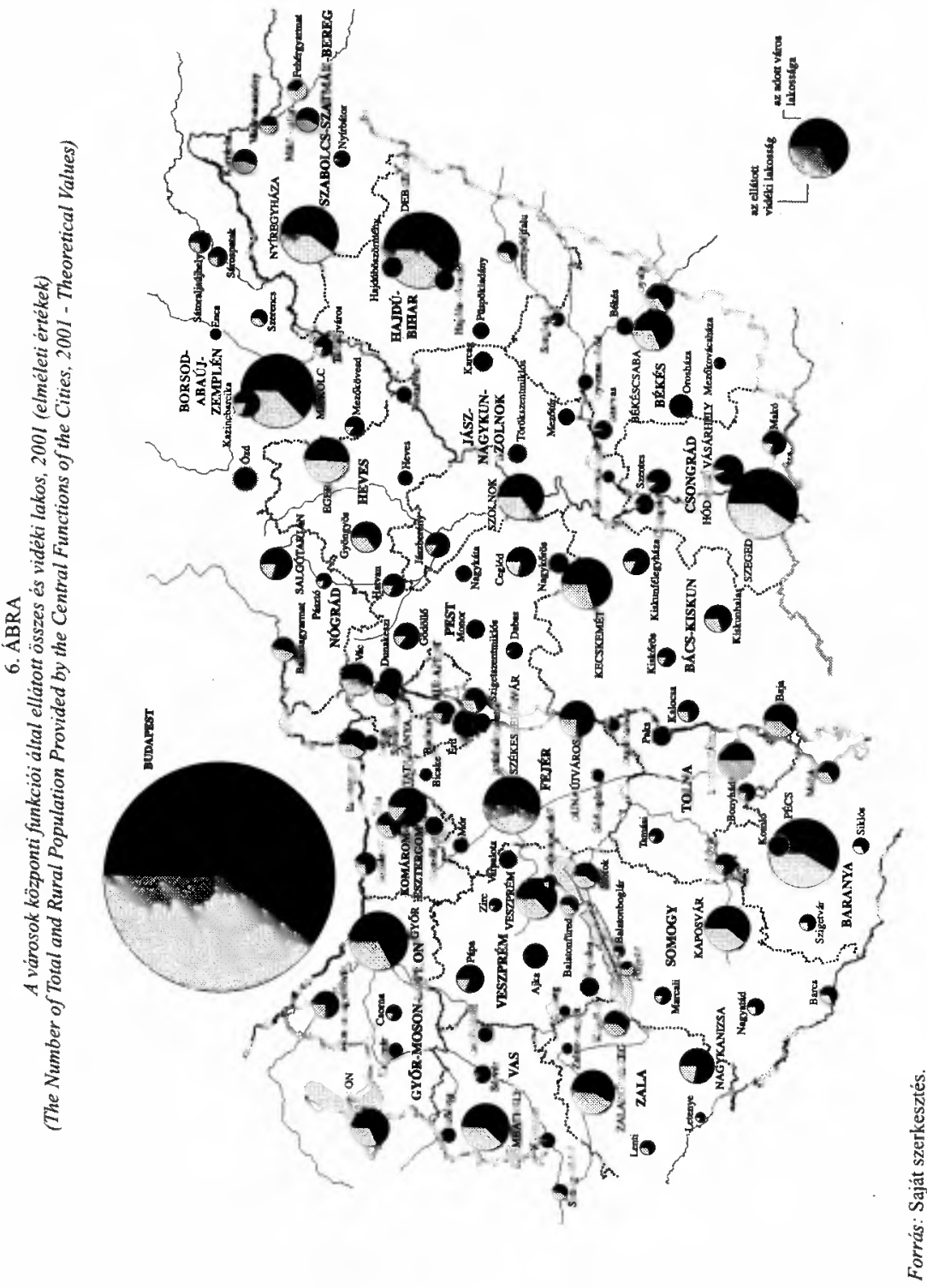


Beluszky Pál - Győri Róbert : Fel is út, le is út... (Városaink településhierarchiában elfoglalt pozícióinak változásai a 20. században.) Tér és Társadalom 18. évf. 2004/1. 1-41. p.

Fel is út, le is út ...

\section{TÁBLÁZAT}

A városi funkciókkal ellátott lakosság 1910-ben és 2001-ben

(Population with Civic Functions in 1910 and 2001)

\begin{tabular}{|c|c|c|c|c|c|c|c|c|c|c|c|}
\hline $\begin{array}{l}\text { Hierarchia- } \\
\text { szint }\end{array}$ & & $\begin{array}{l}\text { Tele- } \\
\text { pü- } \\
\text { lések } \\
\text { száma } \\
1910\end{array}$ & $\begin{array}{c} \\
\text { Népes- } \\
\text { ség } \\
1910\end{array}$ & $\begin{array}{c}\text { Átlagos } \\
\text { ellátott } \\
\text { összes } \\
\text { lakos- } \\
\text { ság } \\
1910\end{array}$ & $\begin{array}{c}\text { Átlagos } \\
\text { ellátott } \\
\text { vidéki } \\
\text { lakos- } \\
\text { ság } \\
1910\end{array}$ & $\begin{array}{c}\text { Vidéki } \\
\text { ellá- } \\
\text { tott/vá- } \\
\text { rosi } \\
\text { népes- } \\
\text { ség } \\
1910 \\
(\%) \\
\end{array}$ & $\begin{array}{c}\text { Tele- } \\
\text { pü- } \\
\text { lések } \\
\text { száma } \\
2001\end{array}$ & $\begin{array}{l}\text { Népes- } \\
\text { ség } \\
2001\end{array}$ & $\begin{array}{c}\text { Átlagos } \\
\text { ellátott } \\
\text { összes } \\
\text { lakos- } \\
\text { ság } \\
2001\end{array}$ & $\begin{array}{c}\text { Átlagos } \\
\text { ellátott } \\
\text { vidé́ki } \\
\text { lakos- } \\
\text { ság } \\
2001\end{array}$ & $\begin{array}{c}\text { Vidéki } \\
\text { ellá- } \\
\text { tott/vá- } \\
\text { rosi } \\
\text { népes- } \\
\text { ség } \\
2001 \\
(\%) \\
\end{array}$ \\
\hline I. Regioná- & Átlag & & 76295 & 216022 & 139728 & 183 & & 168350 & 271975 & 103624 & 62 \\
\hline $\begin{array}{c}\text { lis közpon- } \\
\text { tok }\end{array}$ & $\begin{array}{l}\text { Ösz- } \\
\text { szeg }\end{array}$ & 4 & 305179 & 864090 & 558911 & & 5 & 841752 & 1359873 & 518121 & \\
\hline \multirow{2}{*}{$\begin{array}{l}\text { II. Megye- } \\
\text { központok }\end{array}$} & Átlag & & 27987 & 81096 & 53109 & 190 & & 74471 & 118959 & 44488 & 60 \\
\hline & $\begin{array}{l}\text { Ösz- } \\
\text { szeg }\end{array}$ & 20 & 559734 & 1621913 & 1062179 & & 13 & 968127 & 1546472 & 578345 & \\
\hline \multirow{2}{*}{$\begin{array}{l}\text { III. Közép- } \\
\text { városok }\end{array}$} & Átlag & & 23946 & 37382 & 13436 & 56 & & 32234 & 44225 & 11990 & 37 \\
\hline & $\begin{array}{l}\text { Ösz- } \\
\text { szeg }\end{array}$ & 21 & 502874 & 785027 & 282153 & & 25 & 805861 & 1105623 & $299) 762$ & \\
\hline \multirow{2}{*}{$\begin{array}{l}\text { IV. Kisvá- } \\
\text { rosok }\end{array}$} & Átlag & & 7889 & 10537 & 2649 & 34 & & 16429 & 17750 & 1321 & 8 \\
\hline & $\begin{array}{l}\text { Ösz- } \\
\text { szeg }\end{array}$ & 79 & 631086 & 842998 & 211912 & & 78 & 1281453 & I 384480 & 103027 & \\
\hline $\begin{array}{c}I-I V . \ddot{o s s z e-} \\
\text { sen }\end{array}$ & & 124 & 1998873 & 34114027 & 72115154 & 106 & I2I & 3897193 & 5396448 & 1499255 & 38 \\
\hline
\end{tabular}

Forrás: Saját szerkesztés.

A két időpont összevetésénél feltünik, hogy napjainkra a városhálózat összességében - és minden hierarchiaszinten - romlott a központ/vidék arány, csökkent az ellátott vidéki lakosság száma. Ugyanakkor a városi javakkal ellátott összlakosság száma növekedett. Ez persze nem jelent mást, mint azt, hogy a városokban élők száma e szük száz év alatt gyakorlatilag megduplázódott: a potenciális és a tényleges vonzáskörzet jó részt a „falakon belülre” került. Viszont a városhálózaton belül jelentős strukturális átrendezödés nem következett be: az ellátott népesség arányaiban hasonlóan oszlik meg az egyes hierarchiaszintek között.

Jelentősek a változások a központ/vidék arány által kialakított rangsorban. 1910-ben a rangsor élén nyugat-dunántúli és észak-magyarországi kis- és középvárosok álltak, néhány megyeközponttal soraikban. Olyan markáns városi profilú települések ezek, amelyek vagy a dualizmus kori átalakulás nyertesei voltak (pl. Szentgotthárd, Balassagyarmat, Szombathely, Sátoraljaújhely), vạgy szükebbtágabb régiójuk tradicionális központjai (pl. Veszprém, Köszeg, Keszthely). Az alföldi városok közül csupán Kalocsa, Kisvárda és Baja kerülhetett be a legjobbak közé: egyikük sem tartozik a tanyás mezővárosok típusába. 2001-ben magas vidékre jutó hányaddal elsősorban a várostalan, apró- és középfalvakkal sủrún megült Szatmár-Bereg kisvárosi központjai dicsekedhettek (Fehérgyarmat, Vásárosnamény, Mátészalka és Szabolcsból Kisvárda). A megyeközpontok közül a legkisebb népességủ, Szekszárd került ide, amely sokáig Tolna megye várostalan tájának szinte kizárólagos centruma volt, illetve a részben hasonló helyzetú Heves megye 
Beluszky Pál - Győri Róbert : Fel is út, le is út... (Városaink településhierarchiában elfoglalt

pozícióinak változásai a 20. században.) Tér és Társadalom 18. évf. 2004/1. 1-41. p.

34 Beluszky Pál-Györi Róbert

TÉT XVIII. évf. 2004

székhelye: Eger. Jó pozícióját őrzi (csak a rangsorban csúszott hátrébb) pl. Szentgotthárd, Keszthely, Zalaegerszeg, Balassagyarmat vagy Esztergom is.

Tulajdonképpen nem történt jelentôs változás az ellátott összes és az ellátott vidéki lakosság rangsorának élmezőnyében. Továbbra is a regionális centrumok állnak az élen, őket a megyeközpontok követik. Az egykori iparvárosokat leszámítva (pl. Salgótarján, Dunaújváros) néhány város tudta lényegesen javítani pozícióját, pl. a szocializmus megyeszékhely-fejlesztésének egyértelmü nyertese: Nyíregyháza, vagy a budapesti agglomeráció peremén középvárosi szerepében megerősödött Vác. Ugyanakkor a Dunántúl középvárosainak (egykori megyeközpontjainak) jó része (pl. Nagykanizsa, Sopron, Pápa vagy a Duna alföldi oldalán Baja) jelentős pozícióvesztést könyvelhet el.

\section{Városhálózatunk évszázados térbeli átrendezödése - a legközelebbi szomszéd analizis tükrében}

Település-földrajzi kutatásoknál gyakran felmerülő kérdés, hogy a településhálózat-városhálózat térbeli elhelyezkedése mutat-e valamiféle szabályosságot, vagy az elrendeződés teljesen véletlenszerü, esetleg koncentrált. Különösen izgalmas a vizsgálat akkor, ha idöbeli elmozdulásra is kíváncsiak vagyunk: hogyan alakította át a hálózatot a spontán fejlődés, esetleg a központi tervezés-beavatkozás. A kérdés megválaszolására a regionális kutatási gyakorlatban a legközelebbi szomszéd analízis módszerét alkalmazzák (Nemes Nagy 1998, 191-196). A módszer ismertetésétöl eltekintve elörebocsátjuk: koncentráltnak tekinthető egy ponteloszlás (esetünkben a városok eloszlása), ha az index értéke 0 és 1 közé esik; véletlenszerü eloszlásokra pedig 0,9 és 1,3 közötti értékek jellemzőek. A 2-es érték felé való elmozdulás szabályos alakzat irányába mutat, négyzetrácsos ponteloszlásnál az index értéke 2; az elméleti maximumot pedig a hatszöges térlefedés jelenti, ebben az esetben az index $\mathrm{L}=2,149$. Jelen kutatásunkban az elemzést három időpontra $(1910,1965,2001)$ végeztük el, egyaránt vizsgálva a városi címmel rendelkezö települések körét, illetve (a hierarchiavizsgálatok alapján) a városi funkciókat betöltő települések körét. (Ez utóbbi esetben a kisvárosi szinttel bezárólag húztuk meg a városok alsó határát.) A vizsgálat eredményét az 5. táblázat mutatja be.

A vizsgálat legfontosabb eredménye, hogy bár a közigazgatási ranggal elismert városok száma megtöbbszöröződött, illetve a városhierarchián belül is jelentös mozgások zajlottak le, a városállomány alapvetỏ térbeli struktúrája nem változott. Ez egyrészt azt jelenti, hogy a tömeges várossá nyilvánítás térben egyenletesen zajlott le, nem alakultak ki városi koncentrációk, a véletlenszerủ eloszlás pedig a több évtizedes településhálózat-tervezés ellenére nem fordult át szabályos térbeli alakzattá. Másrészt megállapítható, hogy a városi funkciót betöltő települések száma nem növekedett az elmúlt majd' száz év során (söt 1965-höz képest napjainkra csökkent), az átrendeződés ellenére alapvetö térbeli szerkezete állandó maradt. A városi címmel rendelkezö települések számának felduzzadása mindenesetre a szabályosság irányába történő csekély elmozdulást eredményezett. A táblázatok össze- 
Beluszky Pál - Györi Róbert : Fel is út, le is út... (Városaink településhierarchiában elfoglalt pozícióinak változásai a 20. században.) Tér és Társadalom 18. évf. 2004/1. 1-41. p.

vetéséből az is leszürhető, hogy a funkcionális városállomány térszerkezete minden időpontban szabályosabb, mint a ,jogi" városállományé.

\begin{tabular}{|c|c|c|c|}
\hline \multirow{3}{*}{$\begin{array}{c}\text { A magyar váro } \\
\text { (Spatial Realignme } \\
\text { Évszám }\end{array}$} & $\begin{array}{r}5 . \\
\text { anali } \\
\text { Neigat térbeli } \\
\text { of the Hunga }\end{array}$ & $\begin{array}{l}\text { 3LÁZAT } \\
\text { ndezödése - a l } \\
\text { eredményei } \\
\text { a City Network- } \\
\text { r Analyses) }\end{array}$ & $\begin{array}{l}\text { zelebbi szoms } \\
\text { come of the } N\end{array}$ \\
\hline & \multicolumn{3}{|c|}{ Közigazgatási városállomány } \\
\hline & Elemszám & $\begin{array}{c}\text { Átlagtávolság } \\
(\mathrm{km} .)\end{array}$ & $L$-érték \\
\hline $1910^{*}$ & 42 & 28,2 & 1,20 \\
\hline 1965 & 64 & 23,1 & 1,21 \\
\hline \multirow[t]{2}{*}{2001} & 252 & 13,0 & 1,35 \\
\hline & \multicolumn{3}{|c|}{ Városi funkciójú települések } \\
\hline Évszám & Elemszám & $\begin{array}{c}\text { Átlagtávolság } \\
(\mathrm{km} .)\end{array}$ & $L$-érték \\
\hline $1910^{*}$ & 126 & 18,8 & 1,38 \\
\hline 1965 & 142 & 17,5 & 1,37 \\
\hline 2001 & 122 & 18,7 & 1,36 \\
\hline
\end{tabular}

* A mai országterületre számolva

Forrás: Saját szerkesztés.

\section{A városhierarchiában bekövetkezett változások összegzése}

1) A 20. század urbanizációja nem jelentette a városi funkciójú települések számának látványos emelkedését. A sokoldalú városi funkciókkal rendelkezö, egyértelmủen városi szerepkörü települések száma (a kisvárosi szintig bezárólag) a mai országterületen a 20. század elejéhez képest alig változott. Mindeközben természetesen megtöbbszöröződött a városi funkciójú intézmények és a városokban élö lakosság volumene is. A városi népesség arányának növekedése azt eredményezi, hogy a városi intézmények szolgáltatásainak nagyobb hányada a ,saját” lakosság ellátását szolgálja, és nem a ,vidéki” lakosságét.

2) Noha korábban - elsősorban a „szocialista” korszakban, de annak elötte is - a közigazgatási szerepkörök és a településhierarchiában elfoglalt helyzet között szoros kapcsolat alakult ki, ma már a várossá-nyilvánítások nincsenek hatással a településhálózati pozícióra.

3) A városhierarchia struktúrája szilárdnak bizonyult a 20. században. Lényeges változás e téren nem várható. A régiók ,hivatalos térszerkezeti egységgé" való szervezése növelheti a régióközpontok szerepét, városi intézményhálózatuk bỏvủlhet. A modernizáció hierarchikus modell szerinti terjedése is a regionális 
Beluszky Pál - Győri Róbert : Fel is út, le is út... (Városaink településhierarchiában elfoglalt

pozícióinak változásai a 20. században.) Tér és Társadalom 18. évf. 2004/1. 1-41. p.

36 Beluszky Pál-Györi Róbert

TÉT XVIII. évf. 2004

központok helyzetét javíthatja. Miután számos városi intézmény ma már nem kötődik a közigazgatási beosztáshoz, elképzelhetô, hogy ezen intézmények megyeközpont-szintü koncentrációja csökken, az erösebb középvárosok is elsősorban a piaci szerveződésủ funkciók terén - felzárkózhatnának a megyeszékhelyek mögé. E folyamat azokban a megyékben haladhat elöre, ahol fejlett középváros található (mint Zalában Nagykanizsa, Veszprémben Pápa, Fejér megyében Dunaújváros, Bács-Kiskunban Baja), vagy ahol a megyében „centrifugális” erök uralkodnak (mint Nógrádban), ill. ahol középvárosi szinten városhiány mutatkozik, s célszerủ lenne itt a középvárosi fejlődést támogatni, mint a szatmári-beregi részeken, esetleg Zemplénben. Ez a folyamat azzal járhat, hogy a középvárosok csoportja tovább differenciálódik, néhányuk felzárkózik a megyeközpontok mögé, mások a kisvárosok közé süllyednek. A kisvárosi szint alá a 20. század során számos település süllyedt, közülük nem egy jelentős városi tradíciókkal rendelkezik, esetleg kicsiny, de markáns hinterlandjuk van, vagy egykori alföldi mezövárosok lévén lélekszámuk magas (pl. Vasvár, Tokaj, Szécsény, Csurgó, Balmazújváros, Hajdúnánás, Bácsalmás, Jászapáti, Túrkeve stb.). E kisközpontok városi szerepkörének bővülése mindenekelött a lakosság vásárlóerejének növekedésétől remélhető.

4) A struktúra szilárdsága ellenére az egyes szintek állománya jelentös mértékben cserélödött. Különösen figyelemre méltóak $-\mathrm{s}$ helyzetük területfejlesztési szempontú elemzést kíván - a tartósan hanyatló városok, hisz a pillanatnyilag azonos hierarchia-szintủ települések közül rosszabb helyzetben vannak az oda lesüllyedők, mint az oda felemelkedők. E városokat korábban felsoroltuk, helyzetüket is vázoltuk. Itt csak a legkirívóbb eseteket említjük újra:

- Sátoraljaújhely szinte az egész 20. század folyamán „süllyedt”, pedig „középváros-hiányos” térségben fekszik, s hanyatlása tovább nehezíti a környező depressziós térségek helyzetét.

- Balassagyarmat sorsa hasonlatos Sátoraljaújhelyéhez, noha ma kedvezöbb a hierarchikus pozíciója, mint a zempléni városé.

- Jó néhány korábbi középváros szállt alá a kisvárosok közé, ezek egy része ma nem is nagyon van hivatva magasabb funkciók ellátására, mások esetében azonban a kisvárosi szerepkör nem feltétlenül indokolt (Jászberény, Makó, esetleg Mohács stb.).

- Még számosabb 20. század eleji karakteres kisváros városi szerepköre vált jelentéktelenné, gyakorta egy erỏs vetélytársnak a közelben való felnövekedése nyomán. Mivel egyszer már városi szintre emelkedtek, lakóik többnyire igénylik - érzelmi alapon is - ezt a szerepkört, „tervszerü" kárpótlásuk erōs alkotó energiákat szabadíthat fel, jelenlétük színesítheti a településhálózatot. Funkciómegosztás, speciális városi funkciók letelepítése részben visszaadhatná e települések korábbi rangját. E települések sora hosszú, csak néhányukat említjük újfent: Devecsert, Csurgót, Abaújszántót, Putnokot, Sellyét, Pécsváradot, Vasvárt. 
Beluszky Pál - Györi Róbert : Fel is út, le is út... (Városaink településhierarchiában elfoglalt pozícióinak változásai a 20. században.) Tér és Társadalom 18. évf. 2004/1. 1-41. p.

5) A felemelkedésnek három fontosabb forrása volt a 20. században: az iparosodás - szinte valamennyi ún. szocialista városunk legalább a kisvárosi szintet elérte -, az idegenforgalom - a balatonparti városok kialakulása - és az agglomerálódás. Feltünő, hogy a településhálózati helyzet - a városi funkcióik iránt támasztott igény -, ill. a közigazgatási szerepkör mily kevés városunkat emelte fel a 20. században. Ez utóbbit részben magyarázza, hogy járási székhelyeink már az 1870-es években kijelöltettek. A közigazgatási funkció elsősorban „,́́j” megyeszékhelyeinket emelte meg a hierarchikus rangsorban - Tatabányát, Salgótarjánt, Békéscsabát, bizonyos fokig Kecskemétet -, ill. az ötvenes évektől hozzájárult a megyeközponti szint markáns jellemzöinek kialakulásához. Alsóbb szinteken csupán Lenti, Encs, Vásárosnamény sorolható a településhálózati igény nyomán kialakult kisvárosok közé. A közigazgatás pontosabban a közigazgatási funkció elvesztése - inkább egy sor városunk hierarchikus helyezésének csökkenését váltotta ki.

6) A „közigazgatási determinációnak” a rendszerváltást követően csökkenö szerepe már értékelhetỏ a hierarchiában bekövetkezett változásban - pl. Sopron bekerülése a megyeközpontok közé, ugyanakkor Salgótarján szerepcsökkenése -, ám e téren csak a jövőben várhatóak jelentősebb változások.

\section{Jegyzetek}

1 A meghatározás pontosítása érdekében hozzátesszük, hogy a településtudományban elfogadott a települések által ellátott szerepkörök „,múködési rádiusz” szerinti hármas felosztása:

- A helyi (alapfokú, lokális) szerepkörök a tágabb értelemben vett szolgáltatások „mindennapi” szükségleteket ellátó tevékenységei (a szolgáltató ágazatok „saját" hierarchiájának alsó fokán álló intézmények tevékenységei, pl. az elemi iskolák, „háziorvosok”, élelmiszerbolt, községi adminisztráció, postai alapszolgáltatások, egyházközségek stb.).

- A városi alapfunkciókon vagy központi („központi helyi”) funkciókon a szolgáltató ágazatok hierarchiájában magasabb szinteken álló, kevésbé mindennapi igényeket kielégítö intézményeket, tevékenységeket értjük (tehát pl. a közép- és felsöfokú oktatást, a kórházakat és szakrendelöintézeteket, klinikákat, bíróságokat, a luxuskereskedelmet stb.), melyek szolgáltatásaikkal, ,városi javakkal" az e szempontból funkcióhiányos „vidéket" is ellátják.

- A speciális (régión túlnyúló hatókörü) funkciók jelenléte a településhálózat egyes elemeiben nem szükségszerủ, tevékenységük eredménye - az ,,áru” - nem kötődik szorosan a települések lakosságához; ilyen tevékenység (funkció) manapság pl. a gyáripar tevékenysége, az idegenforgalom stb.

- A városokban a földrajzi munkamegosztás eredményeként a „központi" funkciók koncentrálódnak, bizonyos fokú mennyiségi-minőségi (sokféleség!) koncentráció nyomán alakulnak ki a városi funkciojú települések.

${ }^{2}$ Oudin idézi Micheletet (Historie de la Rēvolution française), aki így lelkendezett Párizsról írván: „A földgömbnek ezen a centrális pontján, ahol az összes mágneses áramlatok találkoznak és áthatják egymást, behatolhatnak a fenséges misztériumba, az eszmék láthatatlan, öntörvényü keveredésébe" (én.).

3

Ezek sorában újra s újra felbukkan a várost a szabadság szintereként meghatározó nézet. B. Oudin is abban látja a város „hivatását”, hogy az a „,szabadság helyszíne”. „Ha egy szóban kellene definiálnunk a városi koncentráció létjogosultságát, azt mondhatnánk, sajátos hivatása, hogy a szabadság helyszine legyen". (Oudin én.) Ezt a szabadságot értelmezhetjük a városi kiváltságok által garantált szabadságjogokként, a rendi társadalmakban a feudális kötöttségektől való mentességként, a városi önkormányzatok, céhek, a polgárok szabadságaként, de értelmezhetỏ tágabban is: a városi „„ömeg” biztosította arctalanságként, anonimitásként, a lazább társadalmi kontrollként, de mindenekelött a válasżtás lehetőségeként. „Mi indokolja a 'szabadság' szót, amikor a város fogalmát gyakrabban asszociálják a polgárságéval? A szabadság ugyanis az élet minden területén elméleti marad, ha nem párosul a gyakorlatban a választás lehetỏségével. A választás megvalósulásához pedig a választék megléte szưkséges. 
Beluszky Pál - Györi Róbert : Fel is út, le is út... (Városaink településhierarchiában elfoglalt

pozícióinak változásai a 20. században.) Tér és Társadalom 18. évf. 2004/1. 1-41. p.

Súlyos tévedés a kényszerben és elnyomásban látni a szabadság egyetlen akadályát ... Csak a város teszi lehetővé az ember számára, hogy másoktól különbözöönmagára eszméljen, és ugyanakkor talál. kozzék más, a többiektöl hozzá hasonlóan különbözö lényekkel" - summázta a város nyújtotta szabadságról való vélekedését Oudin (én.).

A szociológia, ill. a kultúrantropológia „meditációi” vezetnek át a konkrét, statisztikai adatokkal, topográfiai koordinátákkal jól-rosszul megragadható ,,várostól” az „eszmék világában létező” városig, az ezt a síkot definiáló városfogalmakig. Pl. Park, a városszociológia „klasszikusa” szerint „... a város lelkiállapot, szokásokból és hagyományokból, a szokások keretében szerveződő, s a hagyomány által közvetített viselkedésformákból és érzelmektöl összetevődö egész." (Park 1925) Niedermüller Péter is úgy véli, hogy ,... a városok nem csak formájukat, építészetüket tekintve különböznek egymástói, hanem elsősorban azért, mert a városok lakói másképpen élik meg saját városukat, és ezeken az eltérő „megéléseken” keresztül másképpen teremtik meg azt; mert a mindennapi életüket élö emberek másképpen alkotják meg önnön képüket a városról és ez a másképpen alkotott kép nagyon különbözö városokat hoz létre, azaz a közigazgatásilag ott lévő, egy adott fizikai teret elfoglaló város mindig másképpen és másképpen válik az 'elképzelt' várossá, az egyedül valóságos várossá, amiben élni lehet". (Niedermüller 1994).

${ }^{4}$ Különösen a rokontudományok városvizsgálatai nem tesznek eleget e követelményeknek (gyakorta abban bízva, hogy az általuk alkalmazott matematikai-statisztikai módszerek majd automatikusan „rendet vágnak” a legkülönbözöbb szempontokat tükröző mutatók rengetegében).

Pl. Vörös Károly Pécs 20. század eleji városhálózatban elfoglalt helyzetéről írott tanulmányában 64 mutató alapján vizsgálta 24 törvényhatósági jogú város helyzetét az 1910-es években. Az adatbázis „kezelésére” a rangszám-módszert alkalmazta, mely eljárús a Szerző szerint „... kétségtelenül nyers és elég kezdetleges módszer..." A nyert eredményeket azonban nem ez, hanem a mutatók által képviseit vizsgálati szempontok keveredése teszi kérdésessé. A mutatók egy része a városok központi funkciónak volumenét méri - pl. a pénzintézeti vagyon nagysága, a nyomdaüzemek száma (?) -, mások a település nagyságával állnak kapcsolatban - pl. a népesség száma, a lakóházak száma, a keresők száma, a postai jövedéki bevétel, az iskolai osztályok száma (az iskolatípustól függetlenüi), a rendőrség létszáma stb. -, megint mások a "fejlettséget" tükrözik - pl. az egy lakásra jutó szoba, a kőbỏl vagy téglából épült lakások száma stb. -, vannak a funkcionális típusra vonatkozó adatok - pl. a keresö népesség foglalkozási megoszlása, a gyáripari üzemek száma stb. -, a dinamikára vonatkozóak - az 1869-1910 között bekövetkezett népességszám-váitozás - $\mathrm{s}$ olyanok, amelyek nehezen kapesolhatók a városhálózatban elfoglalt helyzethez - mint pl. a 20-24 évesek között a házasulandók aránya, a sztrájkok miatt kiesett munkanapok száma vagy a bortermelés hektoliterben. Az adatbázis sokoldalú megközelítést tett volna lehetővé, a vizsgálati szempontok-megközelitések tisztázatlansága miatt azonban nem rajzolódhatott ki egyértelmü kép Pécs városhálózati helyzetéröl. Szinte pontosan ugyanez mondható el Bácskai Vera és Nagy Lajos 19. század elejére (1828) vonatkozó kutatásairól, melyekben szintén a településhálózati helyzet, ill. a városhierarchia kimutatása volt a cél, ám a heterogén „mutatórendszer” következményeit még a faktoranalízis alkalmazása sem tudta kiküszöbölni.

${ }^{5}$ Ilyen ,hierarchikus láncot" alkot pl. a kiskereskedelemben az alapvetö élelmiszereket, napi cikkeket árusító szatócsbolt $\rightarrow$ a specializált élelmiszerbolt $\rightarrow$ a háztartási bolt $\rightarrow$ ruházati szaküzlet $\rightarrow$ használtautó-kereskedés $\rightarrow$ autós márkabolt $\rightarrow$ mükereskedés; ez esetben az igénybevétel gyakorisága, a fenntartásukhoz szükséges vásárlóközönség száma alakítja a hierarchikus rangsort. A közoktatásban az óvoda $\rightarrow$ az általános iskola alsó tagozata $\rightarrow$ felső tagozata $\rightarrow$ a középiskolák $\rightarrow$ a föiskolák, egyetemek alkotják a hierarchikus láncolatot; ezen intézmények egymásra épülése nyilvánvaló. A városi bíróságokat $\rightarrow$ megyei bíróságot $\rightarrow$ a táblabíróságokat $\rightarrow$ és a Legfelsőbb Bíróságot bizonyos szervezeti kapcsolatok is hierarchikus láncba füzik.

${ }^{6}$ Így járt el W. Christaller, aki a telefonállomások ,jelentőségtöbbletét” határozta meg, azt számítva ki, hogy egyes településeknek a regionális átlaghoz képest több vagy kevesebb telefonelőfizetöje van-e, mint amennyi lakosságszáma alapjân megilletné. Ezt a megkőzelítést alkalmazta Major Jenô a már

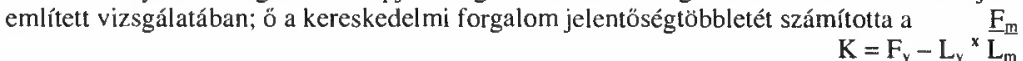

képlettel, ahol a $K$ a központ jelentöségtöbblete, $F_{v}=a$ város szaküzleteinek éves forgalma, és $\mathrm{L}_{\mathrm{m}}=\mathrm{a}$ megye lakosságszáma. Teljesen hasonló eljárást alkalmazott Gál Zoltán a 20. század eleje pénzintézeti hierarchiájának meghatározásakor.

${ }^{7}$

Magyarországon pl. Hódmezővásárhelynek - alig 2-3 kơzség tartozván vonzásterületéhez - ,jelentöségtöbblete" elenyésző, szemben pl. a valamivel szerényebb városi funkciókkal rendeikezỏ Pápával vagy Gyöngyössel, ahol a városi szolgáltatások jelentékeny hányada ,jut vidékre”. (Vizsgáltuk - $\mathrm{s}$ a későbbiekben ismertetjük - a városok központi funkciójú intézményeinek szerepét a vidék ellátásában. Kiszámítottuk a városi intézmények ,,jelentőségtöbbletét”; Hódmezővásárhely esetében a városi szolgáltatásoknak 1,7\%-a, Pápa esetében 21,9\%-a, Gyöngyös esetében 37,5\%-a ,jut vidékre”.) Ezért Hódmezővásárhely nem tekinthető városnak? 
Beluszky Pál - Győri Róbert : Fel is út, le is út... (Városaink településhierarchiában elfoglalt pozícióinak változásai a 20. században.) Tér és Társadalom 18. évf. 2004/1. 1-41. p.

8

Ezek részletes számbavételére itt nincs lehetőségünk, csupán megemlítjük, hogy a negyvenes évek végétöl

- az állam a társadalom és a gazdaság szinte minden szegmensét teljes ellenőrzése-irányítása alá vonta; államosította a társadalmat és a gazdaságot. Ez egyben a társadalom és gazdaság - $\mathrm{s}$ benne a településhálózat - „felülröl" való irányítottságát, a piaci viszonyok kikapcsolását, az. autonómiák - így a települési autonómiák - felszámolását, az erős urbanizációt jelentette.

- A városi funkciójú intézmények tulajdonosa is - közvetlenül vagy közvetve - az állam lett. Ezen intézmények létesítése, megszüntetése, fenntartása, fejlesztése, „profiljának”, olykor mủködési területének meghatározása szintén - végsö soron - állami feladat volt, ,felülről” történt.

- Mindez az intézményszervezés terén az uniformizáltságot, a koncentrációt, a szük ,választékot”, egyes intézmények monopolizált helyzetét, a közigazgatási beosztáshoz való erös kötödést eredményezte. Pl. banki szolgáltatásokat évtizedeken át csak az MNB és az OTP látott el az országban, egységes hierarchikus rendszerbe foglalva, azonos hatáskörökkel, tevékenységi fajtákkal. Ilyen körülmények között pl. „regionális pénzügyi központok” kialakulása elképzelhetetlen volt. Hasonló elvek szerint mủködött az egészségügytől kezdve a helyi sajtóig az államosított társadalom szinte minden intézménye. A városi intézmények müködési területeit is többnyire adminisztratív úton jelölték ki, azok a közigazgatási határokhoz igazodtak; ebböl következett, hogy a közigazgatási központok szinte azonos intézményhálózattal rendelkeztek, s nemcsak az államigazgatás területén, hanem az „államosított" társadalmi-gazdasági feladatok ellátása terén is (múzeumi igazgatóságok, megyei könyvtárak, levéltárak, idegenforgalmi hivatalok, távirati iroda, napilapok és így tovább). Ez az intézménytelepítési elv pl. a megyeszékhelyek intézményhálózatát, hierarchia-szintjét igen hasonlatossá tette, a „,megyeszékhely-szint" meglehetösen zárt, masszív településcsoportot jelentett évtizedeken át.

1990 után a piaci szervezödés, a piaci szempontokat figyelembe vevő telephelyválasztás ismét teret nyert, föleg a gazdaságban, a vállalkozások terén, a szolgáltatásokban, ám a legtöbb „költségvetési” intézmény $\mathrm{ma}$ is a „régi” gyakorlat alapján szervezödik, akár indokolt ez, akár nem. Ezért bizonyul még napjain kban is "mozdulatlan" település-csoportnak a megyeszékhelyek köre, és ezért tükröződnek még ma is a hat vanas-nyolevanas évek egyes közigazgatás-szervezési döntései mindmáig a városhálózaton, a településhierarchián. (Pl. a járási székhely-rangjukat „korán” elvesztő települések városi szerepkörét erösen megviselte a döntés, s a városi rangra való emelés késöbb nem „állította” helyre városi szerepkörüket.)

Természetesen a regionális központok „feladatköre” is változott s egyes telepúlések besorolása e hierarchia-szintbe nem volt egyértelmü. 1910-ben Arad és Brassó besorolása kérdéses, s néhány, a megyeközpontok közé került város rendelkezett több regionális intézménnyel: Sopron. Szombathely, Nagyszeben, Marosvásárhely, Miskolc stb. A trianoni határmegvonás után pedig Győr regionális szerepköre bizonyult vitathatónak.

${ }^{10}$ A budapesti szellemi elit, a modern gazdasági ágakhoz kötődő polgárság, Ady és eszmetársai „,fejlödés” iránti lelkesedése mellett (Ady írta: „Sohasem kényeztették el ebben az országban a városokat. De ilyen rosszindulat se tombolt még a városok ellen... A város a láz, a nyugtalanság, a munka és a fejlöđés. Egyszóval a Város: a kultúra.") a politikai elit és „holdudvara" - közhivatalnokok, publicisták, szakírók stb. - körében a városellenesség már a dualizmus korában is általánosnak mondható. A városellenes publicisztika első számú célpontja Budapest. Példánkat egy „tudományos” müből Mártonffy 1938 - vettük: „Minden, ami szép, ami drága, az egyetlen kedvencre halmoztuk s a kúlsőségeken túl nem terjedt vágyunk, akár egy hiú parvenünek. Arra senki sem gondolt, hogy mi a város, a föváros hivatása a nemzet egésze szempontjából s mik a feltételei annak, hogy jól betölthesse ezt a hivatását. Öncélú városiasodás és városimádat vett erőt a nemzeten $s$ az ország népe mintegy bủvölten hordta kincseit a városba, hogy áldozhasson a bálványozott kedvenc oltárán... Nem bánta, hogy a város a magyar nép természetes kivirágzása-e vagy idegenlelkủ Moloch...."

${ }^{11}$ Az 1910-es kisvárosok közül e hierarchiaszintröl kirostálódott települések:

$\begin{array}{ll}\text { 1. Csurgó } & \text { 11. Gyönk } \\ \text { 2. Tokaj } & \text { 12. Vasvár } \\ \text { 3. Battonya } & \text { 13. Devecser } \\ \text { 4. Jászapáti } & \text { 14. Mezöcsát } \\ \text { 5. Kunszentmiklós } & \text { 15. Abony } \\ \text { 6. Hajúnánás } & \text { 16. Tab } \\ \text { 7. Abaújszántó } & \text { 17. Kunhegye } \\ \text { 8. Nagykálló } & \text { 18. Csepreg } \\ \text { 9. Bácsalmás } & \text { 19. Szikszó } \\ \text { 10. Szécsény } & \text { 20. Tiszalök }\end{array}$

21. Edelény

22. Túrkeve

23. Ráckeve

24. Szentlörinc

25. Sásd

26. Enying

27. Lengyeltóti

28. Pécsvárad

29. Adony

30. Vál 
Beluszky Pál - Győri Róbert : Fel is út, le is út... (Városaink településhierarchiában elfoglalt pozícióinak változásai a 20. században.) Tér és Társadalom 18. évf. 2004/1. 1-41. p.

\section{Irodalom}

Beluszky P. (1967) A magyar városok központi szerepköre. - Statisztikai Szemle. 45. 542--563. o.

Beluszky P. (1973) Adalékok a magyar telepuiléshierarchia változásaihoz, 1900-1970. - Földrajzi Értesítö. 22. 121-142. o.

Beluszky P. (1990) A polgárosodás törékeny váza - városhálózatunk a századfordulón. - Tér és Társadalom. 4 13-56, o.

Beluszky P. (1999) Magyarország telepïlésföldrajza. Dialóg Campus, Budapest-Pécs.

Beluszky P. (témavezető) (2003) A magyarországi városok általános áttekintése. Kézirat. MTA RKK Budapesti Osztály, Budapest.

Beluszky P.-Györi R. (2003) „A város a láz, a nyugtalanság, a munka és a fejlödés.” Magyarország városhálózata a 20. század elején. - Korall. 11-12. 199-238. o.

Bulla B.-Mendöl T. (1947) A Kárpát-medence földrajza. Budapest.

Christaller, W. (1933) Die zentralen Orte in Siuddeutschland. Fischer Verlag, Jena.

Enyedi Gy. (1988) A városnövekedés szakaszai. Akadémiai Kiadó, Budapest.

Enyedi Gy. (1996) Regionális folyamatok Magyarországon az átmenet idöszakában. Hirschler Rezső Szociálpolitikai Egyesület, Budapest.

Gál Z. (1997) A magyarországi városhálózat összehasonlító vizsgálata a banki betétforgalom alapján 1910-ben. - Sasfi Cs.-Németh Zs. (szerk.) Kófallal-sárpalánkkal. Rendi-polgári társadalom. 7. Csokonai Kiadó, Debrecen. 50-68. o.

Gyáni G.-Kövér Gy. (1998) Magyarország társadalom-története a reformkortól a második világháborúig. Osiris, Budapest.

Gyimesi S. (1975) A városok a feudalizmusból a kapitalizmusba való átmenet időszakában. Akadémiai Kiadó, Budapest.

Hajdú Z. (2001) Magyarország közigazgatási földrajza. Dialóg Campus, Budapest-Pécs.

Kubinyi A. (1971) A középkori magyarországi városhálózat hierarchikus térbeli rendjének kérdéséhez. Telepilléstudományi Közlemények. 22. 58-78. o.

Major J. (1964) A magyar városhálózatról, - Településtudományi Közlemények. 16. 32-65. o.

Major J. (1974) Adalékok a két világháború közötti magyar településfejlödés történetéhez. - Településtudományi Közlemények. 24.

Mártonffy K. (szerk.) (1938) A mai magyar város. Budapest.

Mendöl T. (1963) Általános településfóldrajz. Akadémiai Kiadó, Budapest.

Mumford, L. (1985) A város a történelemben. Gondolat. Budapest.

Nemes Nagy J. (1998) A tér a társadalomkutatásban. Hilscher Rezsö Szociálpolitikai Egyesület, Budapest.

Niedermüller P. (1994) A város: kultưra, mítosz, imagináció. - Mozgó Világ. 20. 5-17. o.

Oudin, B. (én.) A város védelmében. Corvina. Budapest.

Papp A. (1983) Az Alföld vonzásközpontjai és vonzáskörzetei a XX. században. Az alföldi kutatás feladatai. Békéscsaba. 147-169. o.

Park, R.E. (1925) The City: Suggestions for the Investigtion of Human Behaviour in The Urban Environment. Chicago.

Pounds, N.J.G. (1997) Európa történeti földrajza. Osiris. Budapest.

Prinz Gy. (1914) Magyarország földrajza. Magyar Földrajzi Intézet Rt., Budapest.

Rechnitzer J. (2002) A városhálózat az átmenetben, a kilencvenes évek változási irányai. - Tér és Társadalom. 3. 165-183. o.

Szigeti E. (1997) Urbanizáció, városhálózat, várossá nyilvánítás. - Teriileti Statisztika. 66-82. o.

Vörös K. (1982) Pécs a 20. század elejének magyarországi városhálózatában. - Sándor L. (szerk.) Tanulmányok Pécs város történetéból. Pécs, 73-82. o. 
Beluszky Pál - Győri Róbert : Fel is út, le is út... (Városaink településhierarchiában elfoglalt pozícióinak változásai a 20. században.) Tér és Társadalom 18. évf. 2004/1. 1-41. p.

\section{RISE AND FALL...}

\section{CHANGES IN HIERARCHICAL POSITION OF THE HUNGARIAN CITIES IN THE XX. CENTURY PÁL BELUSZKY - RÓBERT GYÖRI}

In order to survey the changes in the settlement pattern, this essay compares the results of empirical hierarchy research carried out for the years 1910,1965, 1995, 2000, with those of the analysis that was made for specifying the quantitative characteristics of urban functions. Considering the results, we can state that $20^{\text {th }}$ century urbanization did not result in a spectacular increase in the number of settlements with urban functions, and that the structure of the urban hierarchy appeared to be stable for the last century-even if the composition of certain hierarchy levels was altered. We called particular attention to the cities falling back in their hierarchy position (e.g. Sátoraljaújhely, Balassagyarmat, Jászberény, Makó, Mohács etc.) Industrialization, agglomeration and tourism were the three major incentives that caused rise within the urban hierarchy in the $20^{\text {th }}$ century. 